Uniwersytet im. Adama Mickiewicza, Poznań

\title{
Stosunki polsko-niemieckie na tle budowy Gazociągu Północnego (2005-2009)
}

\& września 2005 r. rosyjski Gazprom oraz niemieckie E.ON-Ruhrgas i BASF-Wintershall w obecności prezydenta Władimira Putina i kanclerza Gerharda Schrödera podpisały umowę dotyczącą rozpoczęcia budowy Gazociągu Północnego, który ma służyć do transportu gazu ziemnego. Gazociag będzie przebiegał z miejscowości Babajewo w rosyjskim obwodzie wołogodzkim do brzegu Morza Bałtyckiego w Wyborgu, a następnie dnem Morza Bałtyckiego do Lubinia koło Greiswaldu w Niemczech. Jego całkowita długość ma wynieść 1220 km, w tym 1189 km wyniesie odcinek podmorski. Do 2009 roku akcjonariuszami budującego go konsorcjum Nord Stream były obok Gazpromu (51\%), niemieckie E.ON-Ruhrgas i BASF-Wintershall (po 20\%) oraz holenderskie N.V. Nederlandse Gasunie (9\%). Koszt budowy szacowany był na ok. 7,4 mld euro.

Sygnowanie rosyjsko-niemieckiej umowy zbiegło się w czasie z wyborami parlamentarnymi w Niemczech (18 września) i w Polsce (25 września). Strona polska miała nadzieję, że nowy rząd „wielkiej koalicji” z przewodniczącą CDU Angelą Merkel jako kanclerzem i przedstawicielem SPD Frankiem-Walterem Steinmeierem jako ministrem spraw zagranicznych będzie starał się oprzeć stosunki z Władimirem Putinem na bardziej racjonalnych podstawach, a nie na przyjaźni dwóch polityków, jak za czasów byłego kanclerza Schrödera ${ }^{1}$. Zmiana miała przyczynić się do wzrostu zaufania wobec niemieckich działań na arenie międzynarodowej $^{2}$. We wprowadzeniu podpisanej 11 listopada przez CDU, CSU i SPD umowy koalicyjnej znalazł się zapis, że ,jedność europejska i partnerstwo atlantyckie są fundamentami niemieckiej polityki zagranicznej” i tworzą „podstawę dla naszych relacji z Rosją”. W innej części umowy podkreślono, że w szczególnym interesie RFN leży stabilizacja i modernizacja tego

1 Zob. Niemcy/Ochmann: koalicyjny rzad Merkel wielka szansa dla Polski, „PAP” z dnia 10 października 2005 r.

2 Zob.: Niemcy/,,FAZ”: Zmiana władzy w Polsce obciaży stosunki Warszawy z europejskim Zachodem, „PAP” z dnia 10 września 2005 r. 
kraju, wspomaganie przemian demokratycznych oraz rozbudowa stosunków gospodarczych ${ }^{3}$. Podobny wydźwięk miało exposé wygłoszone przez nową kanclerz w Bundestagu 30 listopada. Merkel nie wspomniała o zamiarze lepszej koordynacji niemiecko-rosyjskiego partnerstwa strategicznego z krajami sąsiedzkimi. O Polsce wspomniała tylko raz w kontekście przezwyciężania kryzysu w Unii Europejskiej ${ }^{4}$. Jeszcze bardziej powściągliwy w określaniu przyszłych relacji z sąsiadami był nowo wybrany premier Kazimierz Marcinkiewicz. W wygłoszonym 10 listopada 2005 roku w Sejmie exposé premier nie przedstawił założeń polityki wobec Niemiec czy Rosji ${ }^{5}$.

Jako że zmiana decyzji nowego rządu federalnego odnośnie budowy Gazociagu Północnego była mało prawdopodobna, strona polska, kierując się zasadami obrony interesu narodowego, zamierzała wykazywać aktywność w jego blokowaniu. Jan Rokita z PO, mówił, że nowy rząd nie zgodzi się na przebieg gazociągu przez polską strefę ekonomiczną na Morzu Bałtyckim6. Jak podkreślał prof. Jerzy Młynarczyk, specjalista od międzynarodowego prawa morskiego i poseł SdP1, zablokowanie tej inwestycji mogło się powieść, ,jeżeli Polska udowodniłaby na przykład

3 Zob. B. Koszel, Polska i Niemcy w Unii Europejskiej. Pola konfliktów i płaszczyzny wspótpracy, Poznań 2008, s. 188, 190. Zob. również: Gemeinsam für Deutschland - mit Mut und Menschlichkeit. Koalitionsvertrag zwischen CDU, CSU und SPD, Berlin 11.11.2005, http://www.cdu.de/doc/pdf/05_11_11_Koalitionsvertrag_Navigierbar.pdf, 15.11.2006; Ch. Meier, Die ,grosse Koalition” und die deutsch-russische Partnerschaft: Kontinuität und neue Akzente, „Przegląd Stosunków Międzynarodowych” 2006, nr 2, s. 120-135; H. Marhold, Deutsche Europapolitik nach dem Regierungswechsel 2005, „Integration” 2006, nr 1, s. 3-22; Niemcy/Merkel przyjeżdza w piatek z pierwszq wizyta do Polski, „PAP” z dnia 1 grudnia 2005 r.

4 Regierungserklärung von Bundeskanzlerin Dr. Angela Merkel vor dem Deutschen Bundestag am 30. November 2005 in Berlin, „Bulletin der Bundesregierung” nr 93-1, z dnia 30 listopada 2005 r., http://www.bundesregierung.de/nn_1514/Content/DE/Bulletin/2001_2005/2005/11/2005-11-30-regierungserklaerung-von-bundeskanzlerin-dr-angela-merkel-vor-dem-deutschen-bundestag-.html, 1.03.2006.

5 Zob. Exposé premiera Kazimierza Marcinkiewicza, Warszawa, z dnia 10 listopada 2005 r., http://www.kprm.gov.pl/archiwum/4751_14848.htm, 15.01.2006. Zob. również: B. Koszel, Polska i Niemcy..., op. cit., s. 189-190.

6 Polska strefa ekonomiczna na Bałtyku to obszar o powierzchni bliskiej jednej dziesiątej terytorium państwa stykający się ze strefami Niemiec, Danii, Szwecji i Rosji. Granice strefy biegną kilkadziesiąt kilometrów od polskiego brzegu. Zob. M. Haykowski, Gazociag Pólnocny zmieni trasę - dalej od Polski, „PAP” z dnia 11 lipca 2007. Zob. również: E. Więcław, Nowa trasa gazociagu, „Rzeczpospolita” z dnia 2 lipca 2007 r. 
przed morskim trybunałem arbitrażowym w Hamburgu, że gazociagg narusza prawa do eksploatacji strefy, stwarza zagrożenie dla środowiska”. Również prezydent Aleksander Kwaśniewski wskazywał na zagrożenia ekologiczne jako jeden z powodów polskich zastrzeżeń wobec budowy gazociagu przez Bałtyk ${ }^{7}$. Natomiast Marek Belka oświadczył, że budowa gazociagu jest decyzją niekorzystną dla Polski, ponieważ odkłada ewentualne powstanie drugiej linii gazociagu jamalskiego ${ }^{8}$, ale „zamiast biadolić” powinniśmy starać się w inny sposób zapewnić większą dywersyfikację w dostawach gazu. Jak powiedział polityk ,nie jest prawdą, że budowa takiego gazociagu wyklucza budowę innego gazociągu, np. łączącego Polskę z Norwegią czy też Skandynawią ",10.

W październiku stały przedstawiciel Rosji przy Komisji Europejskiej - Władimir Czyżow - zapowiedział, że Gazprom ma w planach poprowadzenie od gazociagu bałtyckiego odnóg do wielu państw m.in. Polski. Nie sprecyzował, kiedy miałoby to nastapić, dodał tylko, że „w kolejnym stadium projektu"11. W mniemaniu rządu polskiego, ta rosyjska „uprzejmość" nie niwelowała problemu, gdyż celem nie było jeszcze jedno podłączenie do rosyjskich złóż, ale dywersyfikacja źródeł tego surowca, która zapewniłaby Polsce bezpieczeństwo energetyczne ${ }^{12}$. Obawiano się również, że wybudowanie rurociągu bałtyckiego praktycznie przekreśla

7 Zob. A. Kublik, S. Sowula, Battycki gazociag - bomba ekologiczna?, „Gazeta Wyborcza” z dnia 13 września 2005 r.

${ }^{8}$ Gazociąg Jamajski łączy złoża gazu ziemnego w północnej Rosji (półwysep Jamał) z Europą Zachodnią. Projekt rozpoczął się w 1992 roku, a porozumienie z Polską podpisano za rządów Hanny Suchockiej w 1993 roku. Biegnie przez Rosję, Białoruś i Polskę do Niemiec. Druga nitka gazociągu, czy też jego zmodyfikowana trasa, czyli projekt Amber (rurociąg z Rosji przez Estonię, Łotwę, Litwę i Polskę do Niemiec), wskutek decyzji Federacji Rosyjskiej, do tej pory nie powstała. Zob. J. Steinhoff, Rzadowi niemieckiemu pod rozwage, ,Rzeczpospolita” z dnia 23 grudnia $2005 \mathrm{r}$. Zob. również: Rosja uspokaja Europę, „Rzeczpospolita” z dnia 25 stycznia 2006 r.

9 Jako alternatywne źródła gazu pod uwagę brane były następujące gazociagi skandynawskie: gazociąg Baltic Pipe łączący Danię i Polskę oraz gazociąg norweski, czyli przedłużenie budowanego gazociagu Korstoe (Norwegia)-Goeteborg (Szwecja). W ramach dywersyfikacji źródeł zaopatrzenia w gaz ziemny mówiono również o dostawach gazu skroplonego (ang. Liquefied Natural Gas - LNG) z innych części świata.

10 Zob. A. Grzeszak, M. Ostrowski, Taniec na rurach, „Polityka”, nr 42 z dnia 21 października 2006 r. Zob. również: Szansa na gazociag ze Skandynawii, „Rzeczpospolita" z dnia 12 września 2005 r.

${ }_{11}$ Rosja uspokaja Europę, op. cit.

12 Zob. P. Reszka, P. Zychowicz, Przyłączcie się do gazociagu, „Rzeczpospolita” $\mathrm{z}$ dnia 5 grudnia $2005 \mathrm{r}$. 
szanse na powstanie alternatywnych gazociagów, dlatego zastanawiano się nad wykorzystaniem drogi morskiej ${ }^{13}$.

Podczas grudniowej wizyty kanclerz zapewniała premiera K. Marcinkiewicza, że „Niemcy chcą utrzymywać strategiczne stosunki z Rosją, ale nie ponad głowami Polaków". A. Merkel obiecywała utworzenie polsko-niemieckiej grupy roboczej mającej pracować nad wykorzystaniem niemiecko-rosyjskiego gazociągu również i dla Polski, podkreślając, że gazociag po dnie Bałtyku jest ,sprawą otwartą dla wszystkich zainteresowanych"14. W ramach pobytu odbyło się również spotkanie ministra spraw zagranicznych RP Stefana Mellera z ministrem Frankiem-Walterem Steinmeierem ${ }^{15}$. Delegacje niemieckie miały na celu uspokoić Warszawę, jednakże nie oznaczały zmian przyjętego kursu ${ }^{16}$.

W następnych dniach minister Steinmeier odwiedził Moskwę, gdzie wyraził stanowczą wolę rządu niemieckiego budowy Gazociagu Północnego oraz zaproszenia do współpracy m.in. Polski. Szef niemieckiego MSZ powiedział, iż uważa ,projekt za racjonalny” i dał do zrozumienia, że prace nad tym przedsięwzięciem będą realizowane bez oglądania się na sprzeciwy z zewnątrz ${ }^{17}$. Parę dni później w obecności premiera Rosji Michaiła Fradkowa i ministra gospodarki i technologii Niemiec Michaela Glosa w pobliżu miejscowości Babajewo uroczyście rozpoczęto pracę przy układaniu lądowego odcinka magistrali Griazowiec-Wyborg. Minister Glos podkreślał, że budowa Gazociągu Północnego to „bardzo ważny etap w rozwoju całej gospodarki Unii Europejskiej”, który pozwoli „stabilnie rozwijać się nie tylko dotychczasowym członkom Unii Europejskiej, ale i nowym krajom członkowskim"18. Podczas uroczystości Aleksiej Miller, prezes rosyjskiego Gazpromu, poinformował, iż Gerhard Schröder stanie na czele komitetu akcjonariuszy niemiecko-rosyjskiego konsorcjum budującego gazociag - North European Gas Pipeline Company

13 PGNG uznało, że powinny działać co najmniej dwa porty z instalacjami zdolnymi do przeładunku gazu - w rejonie Gdańska oraz Świnoujścia. Zob. K. Kubiak, Statki zamiast drogich rurociagów, „Rzeczpospolita” z dnia 11 października 2005 r.

14 P. Reszka, P. Zychowicz, Przyłaczcie się.., op. cit.

15 Zob. Spotkanie Ministra Spraw Zagranicznych RP Pana Stefana Mellera z Ministrem Spraw Zagranicznych RFN Panem Frankiem-Walterem Steinmeierem, http://www.pol-niem.pl/index.php?page=1010600000, 15.12.2005.

16 Zob. B. Koszel, Polska i Niemcy..., op. cit., s. 190. Zob. również: P. Jendroszczyk, P. Zychowicz, Trudne tematy krótkiej wizyty, „Rzeczpospolita” z dnia 3 grudnia 2005 r.

17 P. Reszka, P. Zychowicz, Przytaczcie się..., op. cit.

18 Ruszyła budowa Gazociqgu Pótnocnego, „PAP” z dnia 9 grudnia 2005 r. 
(NEGPC). Dyrektorem generalnym miał zostać znajomy Putina i były oficer enerdowskiej Stasi - Matthias Warnig ${ }^{19}$.

Polscy politycy nie tylko skrytykowali decyzję byłego kanclerza o przyjęciu stanowiska w konsorcjum, ale również podkreślali, że forsowany przez Niemców gazociąg jest szkodliwy dla Polski i zagraża środowisku Bałtyku. Jak skomentował poseł PiS oraz przewodniczący sejmowej komisji spraw zagranicznych Paweł Zalewski „musimy otwarcie i głośno pytać na forum Unii, czemu Niemcy angażują się w projekt droższy niż zaakceptowane przez Komisję Europejską i uwzględniające nasze interesy planowane rurociagi Amber i Jamał II". Poseł przekonywał jednakże, iż nie wszystko stracone - ,jestem przekonany, że możemy jeszcze wpływać na politykę Niemiec i będziemy do tego stanowczo dążyć. Europa Zachodnia musi mieć dostawy gazu z różnych źródeł, ale nie mogą one naruszać interesów Polski” ${ }^{20}$.

W styczniu 2006 roku podczas pierwszej wizyty w Moskwie, kanclerz Merkel oświadczyła, że trzeba wyjaśnić krajom bałtyckim i Polsce, że rurociąg biegnący po dnie Bałtyku nie jest wymierzony przeciw komukolwiek. Na wspólnej konferencji prasowej z Putinem podkreślała, że ,jest ważny dla bezpieczeństwa energetycznego Europy"21. Mimo krytyki niektórych posunięć rządu rosyjskiego, nie zamierzała zrezygnować z pogłębiania rosyjsko-niemieckiego strategicznego partnerstwa ${ }^{22}$. Również miesiąc później kanclerz Niemiec bardzo dobitnie wyraziła poparcie dla budowy Gazociagu Północnego mówiąc, że „nie ma sensu ukrywać, że popieramy budowę gazociagu". Polscy dyplomaci byli poirytowani jej wypowiedzią. Jak skomentował minister obrony Radosław Sikorski ,raczej nie przekonało mnie to, co powiedziała pani kanclerz"23.

$\mathrm{Na}$ dwa dni przed zaplanowaną oficjalną wizytą w Berlinie ${ }^{24}$ Lech Kaczyński udzielił wywiadu dla „Der Spiegel”. Prezydent powiedział w nim,

19 Zob. A. Skieterska, Byty kanclerz Niemiec będzie budować Gazociag Północny, „Nowy Dzień” z dnia 10 grudnia 2005 r.

20 Zob. P. Jendroszczyk, Pieniadze $i$ męska przyjaźń, „Rzeczpospolita” z dnia 12 grudnia $2005 \mathrm{r}$.

${ }_{21}$ P. Reszka, Berlin wciaż z Moskwa, ,Rzeczpospolita” z dnia 17 stycznia 2006 r.

22 Zob. B. Koszel, Polska i Niemcy..., op. cit., s. 188. Zob. również: A. Guział, Miejsce Rosji w polityce zagranicznej RFN a szansa na wspólna politykę wschodnia $U E$, „Przegląd Zachodni” 2006, nr 2, s. 43-45.

${ }^{23}$ Berlin nie popiera Warszawy, „Rzeczpospolita” z dnia 6 lutego 2006 r.

24 Do stolicy Niemiec prezydent przyjechał po serii wizyt zagranicznych. Zob. P. Jendroszczyk, Daleka droga do porozumienia, ,Rzeczpospolita” z dnia 8 marca 2006 r. 
że budowa Gazociagu Północnego, jest sprzeczna z polskimi interesami podkreślając, że „nie ma żadnego ekonomicznego uzasadnienia dla tego gazociagu”, a pomysł gazociagu przez Bałtyk „,był wyłącznie natury politycznej”. Dał wyraz swemu rozczarowaniu dodając, że jego rozmowy z kanclerz Angelą Merkel nie przyniosły dotychczas wyników satysfakcjonujących Polskę, gdyż „nie były konstruktywne”25. Z wypowiedzi dla niemieckiego tygodnika wynikało, iż prezydent raczej nie spodziewał się, że dojdzie do porozumienia $\mathrm{w}$ trakcie wizyty $\mathrm{w}$ Berlinie $^{26}$.

Podczas marcowej wizyty niemiecka kanclerz podkreślała, że budowa Gazociągu Północnego już się rozpoczęła, co oznacza, że „trudno byłoby jej zaniechać". Przedstawiając negatywne stanowisko Polski wobec gazociągu prezydent oświadczył, że Polsce chodzi o to „,by nie było możliwości odcinania Polsce dostaw gazu, bez odcięcia ich również dla krajów zachodnich". W ocenie Kaczyńskiego ewentualne wybudowanie odnogi gazociagu do Polski było lepszym rozwiązaniem niż żadne. Zapowiedział, że rozmowy na ten temat będą kontynuowane ${ }^{27}$. Prezydent wyjechał z Berlina w dobrym nastroju podkreślając, że jest zadowolony z przebiegu wizyty. Miał nadzieję, że „możliwe jest znalezienie rozwiązań wszystkich problemów, ale będzie to stopniowy proces"28.

W kwietniu pojawiła się informacja, iż rząd Schrödera poręczył Gazpromowi miliard euro kredytu na budowę odcinka Gazociagu Północnego łączącego syberyjskie pola gazowe z rosyjskim wybrzeżem Bałtyku. Decyzja o gwarancji zapadła 24 października 2005 roku, już po przegranych przez ugrupowania koalicji rządowej gabinetu Gerharda Schrödera wyborach, kiedy wiadomo było, że na stanowisku kanclerza nastąi zmiana. Jako że Schröder wielokrotnie przekonywał, także władze polskie, że bu-

25 Polska/Prezydent Lech Kaczyński udaje się z wizyta do Berlina, „PAP” z dnia 7 marca 2006 r.

26 P. Jendroszczyk, Sasiad, któremu trudno ufać, ,Rzeczpospolita” z dnia 6 marca 2006 r. Zob. również: P. Jendroszczyk, Nie będzie przełomu z Niemcami, „Rzeczpospolita" z dnia 6 marca 2006 r.

27 A. Widzyk, J. Lepiarz, Niemcy/L. Kaczyński w Berlinie: poprawa stosunków polsko-niemieckich jest możliwa, „PAP” z dnia 8 marca 2006 r.

28 Zob. P. Jendroszczyk, Problemy do rozwiazania, „Rzeczpospolita” z dnia 10 marca 2006 r. Zob. również: K. Schuler, Lauter Ärger. Der Auftritt des polnischen Präsidenten Lech Kaczyński in der Berliner Humboldt-Universität verlief turbulent, „Die Zeit online” 2006, nr 4, z dnia 9 marca 2006 r., http://images.zeit.de/text/online/2006/11/Kaczynski; Polska i Niemcy wracaja na stare tory, „Gazeta Wyborcza” z dnia 10 marca $2006 \mathrm{r}$. 
dowa rurociagu pod Bałtykiem jest wyłącznie przedsięwzięciem komercyjnym bez żadnych odniesień do polityki, a ujawnione informacje postawiły pod znakiem zapytania szczerość owych zapewnień, postawa kanclerza wywołała ostre komentarze zarówno w Polsce, jak i w Niemczech. Schröder bronił się słowami, że nie wiedział, iż jego gabinet udzielił Gazpromowi gwarancji. Wspierali go partyjni koledzy. Parę dni później ministrowie Merkel oświadczyli, że poręczenie dla Gazpromu zostało wydane bez uchybień ${ }^{29}$. Postawa rządu „,wielkiej koalicji” świadczyła o tym, że inwestycję tą traktowano priorytetowo jako wstęp do większych porozumień rosyjsko-niemieckich ${ }^{30}$.

Po raz kolejny Polska wyraziła niezadowolenie z rosyjsko-niemieckiego przedsięwzięcia podczas Forum Brukselskiego zorganizowanego przez German Marshall Fund 30 kwietnia. Według słów ministra obrony Radosława Sikorskiego rząd polski poprosił kanclerz Niemiec Angelę Merkel o wycofanie się z popierania tego projektu, ta jednak odmówiła. W ocenie polityka dostawy energii były dla Rosji instrumentem w sporach politycznych, a budowa droższego o sześć miliardów euro od ewentualnego połączenia biegnącego przez terytorium Polski i Białorusi Gazociagu Północnego miała umożliwić wywieranie presji politycznej przez Moskwę na te dwa kraje. Jak żywotne znaczenie miała budowa rosyjsko-niemieckiego gazociagu dla polskich interesów pokazało porównanie przez Sikorskiego projektu do ,paktu Ribbentrop-Mołotow”31. Słowa te można było odczytać jako wyraz rozgoryczenia Warszawy, iż nowemu polskiemu rządowi nie udało się skłonić rządu Angeli Merkel do rezygnacji z porozumienia wypracowanego przez Gerharda Schrödera i Władimira

29 Zob. B. T. Wieliński, Gazociag pótnocny śmierdzi w Niemczech, „Gazeta Wyborcza" z dnia 3 kwietnia 2006 r. Zob. również: P. Jendroszczyk, Gazociag z gwarancja Berlina, „Rzeczpospolita” z dnia 3 kwietnia 2006 r.

30 Zob. B. Koszel, Polska i Niemcy..., op. cit., s. 191-192. Zob. również: Ein schwieriger Gast, „Der Tagesspiegel” z dnia 21 października 2006 r.; J. Franke, Die Russlandpolitik der Großen Koalition. Eine (Zwischen-) Bilans nach einem Jahr, w: Polacy i Niemcy w XX wieku. Nowe oblicza partnerstwa, red. B. Koszel, Poznań 2007, s. 23-34.

31 A. Słojewska, Naciski Moskwy na unijnq energetyke, ,Rzeczpospolita” z dnia 2 maja 2006 r. Zob. również: A. Rahr, Przejaw złości, ,Rzeczpospolita” z dnia 2 maja 2006 r.; Sikorski: Niemcy nie sq solidarne w sprawie Gazociagu Pólnocnego, „Puls Biznesu" z dnia 30 czerwca 2006 r.; R. Götz, Deutsch-russische Energiebeziehungen - auf einem Sonderweg oder auf europäischer Spur? Diskussionspapier. Forschungsgruppe Rusland/GUS, „SWP” 2006, nr 5, z dnia 10 listopada 2006 r. 
Putina $^{32}$. Wzburzyły one opinię publiczną w RFN. Choć oficjalne stanowisko rządu niemieckiego przedstawione przez szefa niemieckiego MSZ Franka-Waltera Steinmeiera było takie, iż rozbieżności w stosunkach dwustronnych są rzeczą całkowicie normalną, oczekiwano wyjaśnieńn ${ }^{33}$. Strona polska nie była jednak skora do ich złożenia. Kazimierz Marcinkiewicz oświadczył w Polskim Radiu, iż „zarówno Niemcy, jak i Rosja, ale i cała Unia Europejska wiedzą doskonale, w jaki sposób my traktujemy ten projekt Gazociągu Północnego. Jest on dla Polski projektem uderzającym w nasze interesy". Polityk dodał, że wielokrotnie pytał, dlaczego ktoś chce na dnie Bałtyku budować gazociąg, który będzie kilkakrotnie droższy od drugiej nitki gazociagu jamalskiego. Jak podkreślił „ze strony biznesowej nie da się udokumentować, że to jest dobry interes. W związku z tym trzeba zadawać pytania o ten gazociag" 34 .

Parę dni później odbyło się Forum Europejskie, na którym gościli zarówno polski premier, jak i Angela Merkel. Po spotkaniu Kazimierz Marcinkiewicz poinformował, że sprawa budowy Gazociagu Północnego była tematem rozmowy w cztery oczy z kanclerz Merkel. Jak oświadczył premier ,nie widzimy rozwiązania, które zmniejszyłoby niebezpieczeństwo wynikające $\mathrm{z}$ tego projektu" i zdementował pojawiające się w prasie polskiej informacje dotyczące przedstawienia kanclerz Merkel polskiej propozycji polegającej na włączeniu do budowy Gazociągu Północnego innych krajów UE ${ }^{35} .12$ maja premier Kazimierz Marcinkiewicz przesłał Polskiej Agencji Prasowej oświadczenie, w którym napisał: „Porozumienie Rosji i Niemiec w sprawie budowy gazociagu bałtyckiego jest porozumieniem, na które nie było i nie ma zgody Polski. [...] W trakcie rozmowy nie padła z mojej strony żadna propozycja udziału Polski w tej inwestycji

32 Zob. P. Jendroszczyk, Gazociag to nie rozbiór Polski, „Rzeczpospolita” z dnia 4 maja 2006 r. Zob. również: A. Słojewska, P. Jendroszczyk, Energia dzieli Europe, „Rzeczpospolita” z dnia 2 maja 2006 r.

33 Zob. P. Jendroszczyk, Polska-Niemcy: Dialog nadal kuleje, „Rzeczpospolita” z dnia 9 maja 2006 r.

34 J. Ordyński, Premier popiera Sikorskiego, ,Rzeczpospolita” z dnia 5 maja 2006 r.

35 Informacje takie podała „Rzeczpospolita” powołując się na Ryszarda Schnepfa. Potwierdził je Paweł Zalewski, szef Sejmowej Komisji Spraw Zagranicznych oraz Artur Zawisza, szef Sejmowej Komisji Gospodarczej. Zob. P. Jendroszczyk, J. Bielecki, Jednym głosem o energetyce, ,Rzeczpospolita” z dnia 10 maja 2006 r. Zob. również: J. Haszczyński, Niepotrzebne wahanie, „Rzeczpospolita” z dnia 10 maja 2006 r.; J. Bielecki, Polska propozycja dla Niemiec, „Rzeczpospolita” z dnia 11 maja 2006 r.; J. Bielecki, Gazociag dla wtajemniczonych, ,Rzeczpospolita” z dnia 11 maja 2006 r. 
ani wprowadzenia przedstawicieli Polski do ciał zarządzających projektem"36. W związku z ujawnieniem koncepcji dotyczącej gazociagu bez porozumienia z premierem, jego doradca - Ryszard Schnepf - podał się do dymisji ${ }^{37}$. Została ona przyjęta, jak spekulowano m.in. ze względu na naciski ze strony braci Kaczyńskich, którzy byli przeciwni udziałowi Polski w budowie Gazociągu Północnego ${ }^{38}$. Dymisja ta była dla Jana Rokity „ostatecznym dementi”, że Polska chciała osiągnąć z Niemcami kompromis w sprawie gazociągu. Jak skonstatował, „teraz jego budowa będzie się posuwać, a nasz kraj nie będzie miał na to żadnego wpływu"39.

W niemieckich kręgach rządowych uważano, że właściwym rozwiązaniem byłoby przyłączenie się Polski do gazociagu poprzez wybudowanie łącznika. Przeważał jednak pogląd, że pragmatyzm nie jest mocną stroną polskich elit o prawicowej orientacji ${ }^{40}$. Niemieccy politycy z obawą przyglądali się nowoutworzonej koalicji będącego u władzy PiS-u z Samoobroną i LPR-em ${ }^{41}$. Pojawiły się określenia w rodzaju ,gabinet strachu" i tezy, że polski rząd zmierza w kierunku nacjonalistycznym ${ }^{42}$. W exposé wygłoszonym 10 lipca nowy szef rządu - Jarosław Kaczyński - nie odniósł się do relacji polsko-niemieckich ani też słowem nie wspomniał o Niemczech jako ważnym sąsiedzie Polski. Przyznał, że „zasadniczym wyznacznikiem naszej pozycji jest nasz udział w Unii Europejskiej” i podkreślał, że w Unii „musimy zachować możliwość podejmowania własnych decyzji, tak jak wiele krajów ma taką możliwość w sprawach, które wiążą się z naszą specyficzną sytuacją historyczną i geopolityczną" ${ }^{43}$. Kanclerz A. Merkel zatelefonowała do nowo wybranego premiera

36 Polska nie zgadza się na budowę gazociagu pótnocnego, ,Rzeczpospolita” z dnia 12 maja 2006 r. Oświadczenie to było odpowiedzią na artykuł J. Bieleckiego zamieszczony dzień wcześniej w „Rzeczypospolitej” pt.: Gazociag dla wtajemniczonych.

37 Zob. J. Bielecki, Ryszard Schnepf zostaje w Kancelarii Premiera, ,Rzeczpospolita" z dnia 13 maja 2006 r.

38 Zob. Doradca premiera: dymisja za Gazociag Pólnocny, „PAP” z dnia 14 maja 2006 r.

39 J. Bielecki, Doradca niczym saper, ,Rzeczpospolita” z dnia 15 maja 2006 r.

40 Zob. P. Jendroszczyk, Polska-Niemcy: Dialog nadal kuleje, ,Rzeczpospolita” z dnia 9 maja 2006 r.

41 Zob. Niemcy o polskim rzqdzie: Nacjonaliści, ekstremiści, klerykałowie, „Gazeta.pl" z dnia 9 maja 2006 r.

42 Ibidem.

43 B. Koszel, Polska i Niemcy..., op. cit., s. 50-51. Zob. również: Exposé premiera Jarosława Kaczyńskiego, Kancelaria Prezesa rady Ministrów, http://www.kprm.gov.pl/ archiwum/1433_18017.htm, 15.07.2008. 
z gratulacjami. Stosunki bilateralne dalekie były jednakże od dobrych, chociażby ze względu na odwołanie przez Lecha Kaczyńskiego spotkania Trójkąta Weimarskiego po pojawieniu się w gazecie „Tageszeitung” niepochlebnego artykułu dotyczącego prezydenta oraz jego rodziny ${ }^{44}$.

W lipcu pojawiła się informacja, że zastrzeżenia zgłaszane przez ekologów mogą doprowadzić do opóźnień w budowie Gazociagu Północnego. Ma on bowiem przebiegać przez jeden z najbardziej chronionych ekologicznie regionów Niemiec, Natura 2000, obejmujący Zatokę Greifswaldzką. Gerhard Schröder zapewniał, że wszelkie ekologiczne zastrzeżenia będą traktowane poważnie ${ }^{45}$. Miesiąc później, North European Gas Pipeline Company poinformowała, że rosyjski Gazprom oraz niemieckie E.ON-Ruhrgas i BASF podpisały w Moskwie porozumienie końcowe dotyczące budowy Gazociagu Północnego. Według NEGPC dokument ten konkretyzował uzgodnienia poczynione w umowie bazowej, a także określał prawne i finansowe ramy projektu ${ }^{46}$. Następnie szef rady nadzorczej konsorcjum - Gerhard Schröder - zapowiedział, że prace przy układaniu na dnie Bałtyku rur do transportu gazu zaczną się na wiosnę 2008 roku, a cała magistrala ma być uruchomiona w lipcu 2010 roku $^{47}$.

3 września 2006 roku na nieformalnym spotkaniu ministrów spraw zagranicznych państw UE w Lappeenranta minister F.-W. Steinmeier przedstawił projekt polityki wschodniej ${ }^{48}$. Nowa EU-Ostpolitik zakładała połączenie Unii z Moskwą wielopłaszczyznowym strategicznym partnerstwem oraz stworzenie europejskiej sieci bezpieczeństwa, której podstawowym elementem miał być Gazociagg Północny, wzbudzający taką

44 Zob. P. Köhler, Polens neue Kartoffel. Schurken, die die Welt beherrschen wollen („Nowy polski kartofel. Szubrawcy, którzy chcą rządzić światem”), „Die Tageszeitung” z dnia 26 czerwca 2006 r. Zob. również: J. Bielecki, Odra znów dzieli, „Rzeczpospolita" z dnia 12 lipca 2006 r.; P. Wroński, K. Katka, Prezydent choruje po szyderczym artykule w ,, Tageszeitung”?, „Gazeta Wyborcza” z dnia 4 lipca 2006 r.; B. T. Wieliński, Glupia satyra wywołała międzynarodowa awanture, „Gazeta Wyborcza” z dnia 6 lipca 2006 r.; P. Wroński, Rząd stara się stonować reakcje po artykule „, Tageszeitung”, „Gazeta Wyborcza” z dnia 6 lipca 2006 r.

45 Zob. P. Jendroszczyk, Wielka rura się opóźni, ,Rzeczpospolita” z dnia 10 lipca 2006 r.

46 Zob. Porozumienie końcowe w sprawie Gazociagu Pólnocnego, „Rzeczpospolita" z dnia 30 sierpnia $2006 \mathrm{r}$.

${ }^{47}$ A. Łakoma, J. Przybylski, Kaczyński chce gazociagu, tylko kto go wybuduje, „Rzeczpospolita” z dnia 5 września 2006 r.

48 Zob. H.-D. Jacobson, H. Machowski, Dimensionen einer neuen Ostpolitik der $E U$, „Aus Politik und Zeitgeschichte” 2007, t. 10. 
niechęć w Polsce. W RFN kategorycznie zapewniano, że od takiej polityki nie będzie odwrotu ${ }^{49}$. Podczas spotkania unijnych przywódców w Lahti, miesiąc później, łatwo było zauważyć, że w kwestii gazociągu bałtyckiego prezydent Lech Kaczyński nie znalazł większego poparcia ${ }^{50}$.

$\mathrm{Na}$ dwa dni przed wizytą w Berlinie, 28 października, Jarosław Kaczyński po raz kolejny podkreślił, że wyklucza udział Polski w budowie niemiecko-rosyjskiego gazociągu przez Bałtyk. Jak oświadczył, ta podmorska inwestycja nie jest dla Polski ani interesująca, ani korzystna. Polska nie zaangażuje się w nią, bo nie potrzebuje dodatkowej drogi transportu rosyjskiego gazu, ale szuka alternatywnych dostaw tego surowca ${ }^{51}$. Podczas briefingu dla prasy premier oświadczył, że stanowisko Polski wobec budowy Gazociągu Północnego jest ,jednoznaczne i niezmienne”, a inwestycja ta godzi w polski interes narodowy i bezpieczeństwo energetyczne kraju. Zapowiedział również, że podczas spotkania z Merkel polskie stanowisko w tej sprawie będzie podtrzymane ${ }^{52}$.Zarówno Kaczyński, jak i szefowa polskiej dyplomacji Anna Fotyga deklarowali przed wizyta, że liczą na poprawę stosunków z Niemcami. W wywiadzie, który ukazał się w niemieckim dzienniku „Der Bild”, Kaczyński zaprzeczył, by od czasu objęcia przez niego stanowiska nastąpiło pogorszenie stosunków, choć przyznał, że od 2000 roku występowały „pewne różnice poglądów i konflikty interesów”. „Zawirowania” w stosunkach polsko-niemieckich, według premiera, rozpoczęły się w chwili, gdy w Niemczech zapadła decyzja o budowie Gazociagu Północnego. Zapewnił jednakże, że uważa, iż ,jest

49 Zob. B. Koszel, Polska i Niemcy..., op. cit., s. 195-196. Zob. również: Ł. Adamski, Niemieckie przewodnictwo w UE-zarys wstęnych koncepcji dotyczacych Europy Wschodniej i Rosji, „Biuletyn PISM” 2006, nr 55; B. T. Wieliński, Niemcy tworza wschodnia politykę UE, „Gazeta Wyborcza” z dnia 18 października 2006 r.

50 Zob. B. Koszel, Polska i Niemcy..., op. cit., s. 192. Zob. Energieversorgung: Russland lehnt EU-Forderungen, „Der Spiegel” z dnia 20 października 2006 r.; Energieversorgung: Putin verweigert Garantien und beschwichtigt, „Frankfurter Allgemeine Zeitung” z dnia 21 października 2006 r.; Putin nie uległ Unii, „Gazeta Wyborcza” z dnia 21 października 2006 r.; A. Słojewska, UE jednym głosem do Putina, „Rzeczpospolita" z dnia 21 października 2006 r.; H. Crolly, EU-Gipfel: Nichts als Worte. Beim EU-Gipfel verweigert Russlands Präsident Putin jede Zusage über ein Energieabkommen. Nun müssen die Deutschen schlichten, „Die Welt” z dnia 23 października $2006 \mathrm{r}$.

51 Zob. A. Łakoma, Polsce potrzebna jest dywersyfikacja, ,Rzeczpospolita” z dnia 30 października 2006 r.

52 Spotkanie z Merkel głównym punktem wizyty Kaczyńskiego w Niemczech, „PAP” z dnia 30 października $2006 \mathrm{r}$. 
to normalne w stosunkach między państwami. Nie ma powodów do niepokoju" ${ }^{, 53}$.

Podczas wizyty w Berlinie A. Merkel zaproponowała włączenie Gazociągu Północnego w system bezpieczeństwa energetycznego Unii i dostawy gazu do Polski w razie rosyjskiego szantażu. Kanclerz zamierzała przekonać Warszawę o konieczności budowy łącznika z końcowej stacji Gazociagu Północnego w Greifswaldzie do granicy Polski. Szczegóły miała ustalić polsko-niemiecka grupa robocza ${ }^{54}$. Polski premier zamierzał zgodzić się na łącznik pod warunkiem złożenia zobowiązań traktatowych i rzeczywistego powiązania europejskich systemów energetycznych ${ }^{55}$.

W listopadzie minister środowiska Jan Szyszko na konferencji prasowej zapowiedział, że „Polska będzie się domagała wykładni ocen oddziaływania Gazociagu Północnego na środowisko. Chcemy także uczestniczyć w ocenie wpływu tego gazociągu na Morze Bałtyckie" ${ }^{\circledR 5}$. Wypowiedź ta zbiegła się w czasie z rozpoczęciem oficjalnych starań o uzyskanie pozwolenia na budowę Gazociagu Północnego przez niemiecko-rosyjskie konsorcjum Nord Stream AG. Wnioski w tej sprawie wpłynęły do Federalnego Urzędu Żeglugi i Hydrografii w Hamburgu oraz Urzędu Górniczego w Stralsundzie ${ }^{57}$.

53 Ibidem.

54 Zob. B. Koszel, Polska i Niemcy..., op. cit., s. 192. Zob. również: Berlin-Warszawa: Merkel oferuje bezpieczeństwo energetyczne, ale nie chce mówić o historii, „Rzeczpospolita” z dnia 31 października 2006 r.; Distanz zwischen Deutschen und Polen bleibt, „Der Tagesspiegel” z dnia 31 października 2006 r.; D. Zagrodzka, Stawka większa niż rura, „Gazeta Wyborcza” z dnia 1 listopada 2006 r.; M. Kamann, Deutsch-polnischer Gipfel. Notwendiger Konflikt, „Die Welt” z dnia 2 listopada 2006 r.; A. Podolski, Gaz narodowy czy europejski. Polityczne i historyczne uwarunkowania percepcji wybranych wyzwań dla bezpieczeństwa energetycznego RP, „Centrum Stosunków Międzynarodowych. Raporty i Analizy" 2007, nr 2.

55 Zob. P. Jendroszczyk, Nowa oferta dla Polski w sprawie gazu, „Rzeczpospolita" z dnia 28 października 2006 r. Zob. również: J. Haszczyński, Niemcy powinni zrozumieć Polaków, „Rzeczpospolita” z dnia 30 listopada 2006 r.; Distanz zwischen Deutschen ind Polen bleibt, „Der Tagesspiegel” z dnia 31 października 2006 r.; P. Jendroszczyk, Gazowa oferta z Niemiec, ,Rzeczpospolita” z dnia 31 października 2006 r.; M. Kamann, Deutsch-polnischer Gipfel: Notwendiger Konflikt, „Die Welt” z dnia 2 listopada 2006 r.; Premier Jarosław Kaczyński złożyt 30.10.06 jednodniowa wizyte robocza w RFN, http://www.pol-niem.pl/index.php?page=1010600000, 3.11.2006; B. Koszel, Polska i Niemcy..., op. cit., s. 53.

56 Zob. M. Kozman, Ocenimy wpływ Gazociagu Pólnocnego na Bałtyk, „Rzeczpospolita" z dnia 10 listopada 2006 r.

57 Zob. Gazociag w Niemczech, „PAP” z dnia 15 listopada 2006 r. 
Sporo zamieszania do niemieckich koncepcji nowej polityki wschodniej wniosła decyzja prezydenta W. Putina z końca 2006 roku o podwyżce cen ropy naftowej dla Białorusi i zamknięciu dopływu do niej tego surowca, a tym samym odcięciu dostaw do Polski, Niemiec, Czech, Słowacji i Węgier. A. Merkel „wypomniała Rosjanom, że w ubiegłych latach Moskwa zakręciła kurek z gazem dla Białorusi i Polski i wstrzymała dostawy gazu do Europy Zachodniej ze względu na spór z Ukrainą. Kanclerz podkreślała, że w sprawie wstrzymania dostaw ropy UE mówi jednym głosem i nie zostawi w potrzebie żadnego kraju" ${ }^{45}$. W związku z zaistniałą sytuacją Polska chciała podzielić się pierwszymi awaryjnymi dostawami ropy ze wschodnioniemieckimi rafineriami. Jak oświadczyła Anna Fotyga liczono na „podobne solidarne działania państw członkowskich UE"59. Zdaniem szefowej rządu kryzys związany ze wstrzymaniem dostaw rosyjskiej ropy do Polski i innych krajów UE miał nieco zmienić kontekst dyskusji na temat bezpieczeństwa energetycznego w UE. Jak zauważyła, ostatnie wypowiedzi, w tym kanclerz RFN, mogły skłaniać do optymiz$\mathrm{mu}^{60}$. Faktycznie, parę dni później Angela Merkel oświadczyła, że „Gazociąg Północny, który ma połączyć przez Bałtyk Rosję z Niemcami, nie może wyrządzić szkód Polsce i krajom bałtyckim". Szefowa niemieckiego rządu opowiedziała się za stworzeniem politycznych gwarancji, które uniemożliwią wykorzystanie tego projektu do odcięcia sąsiadów Niemiec od dostaw energii. Kanclerz wyjaśniła, że Niemcy dyskutowały z Polską o stworzeniu technicznych warunków do przesyłania gazu importowanego ze wschodu z powrotem na wschód, do Polski. Kanclerz zaznaczyła jednakże, że gazociag jest projektem realizowanym przez prywatne firmy, „to znaczy wspieramy go politycznie i nie zgłaszamy żadnych zastrzeżeń" ${ }^{61}$. Następnie w wywiadzie udzielonym m.in. „Rzeczpospolitej” Angela Merkel oświadczyła, że takie kraje jak Polska mają pełne prawo obstawać przy swoim i podkreśliła, że dobrze rozumie to, co dzieje się w państwach Europy Środkowej i Wschodniej, ponieważ sama pochodzi

58 B. Koszel, Polska i Niemcy..., op. cit., s. 194. Zob. również: K. Niklewicz, Unia wściekta na Rosję, „Gazeta Wyborcza” z dnia 9 stycznia 2007 r.; Russische Öllieferung: Moskau zerstört Vertrauen, „,Frankfurter Allgemeine Zeitung” z dnia 22 stycznia $2007 \mathrm{r}$.

${ }^{59}$ Polska propozycja energetycznej solidarności, „PAP” z dnia 10 stycznia $2007 \mathrm{r}$.

60 Zob. ibidem.

61 J. Lepiarz, Merkel: Gazociag Pólnocny nie może szkodzić Polsce, „PAP” z dnia 12 stycznia 2007 r. 
z NRD. Celem szefowej niemieckiego rządu było doprowadzenie do poprawy stosunków z Polską w ciągu najbliższych miesięcy ${ }^{62}$. Jak trudne było to zadanie świadczy chociażby wypowiedź minister spraw zagranicznych Anny Fotygi, która powiedziała w Sejmie, że „nie ma wątpliwości, że stan stosunków został poważnie zachwiany wraz z ogłoszeniem budowy przez partnerów niemieckich i rosyjskich Gazociagu Północnego”. Szefowa polskiej dyplomacji zapewniła, że Polska „cały czas” włącza się w prace, które mają pokazać zarówno Rosji i Niemcom, jak i państwom, które są zainteresowane tym przedsięwzięciem, ,jakie niebezpieczeństwo" kryje się za tym projektem. Wyraziła również nadzieję, że wśród niemieckich partnerów zacznie ,dojrzewać przekonanie o tym, że na rzecz europejskiej solidarności warto być może zrezygnować nawet z bardzo intratnego przedsięwzięcia"63.

21 stycznia 2007 roku A. Merkel spotkała się z prezydentem W. Putinem w jego rezydencji niedaleko Soczi. Niemiecka kanclerz koncentrowała się głównie na bezpieczeństwie energetycznym. Z kolei prezydent Putin zapewniał, że Rosja jest niezawodnym dostawcą oraz postara się rozwinąć drogi przesyłu surowców niezależnie od krajów tranzytowych ${ }^{64}$. Putin zapowiedział również przyspieszenie budowy rosyjsko-niemieckiego gazociągu po dnie Bałtyku, wraz z pomysłem jego odnogi do Polski, chociaż był świadomy negatywnej reakcji Warszawy. Jak oświadczył ,zgadzamy się na wszystkie propozycje, które nie wyrządzą nam szkody"65.

62 P. Jendroszczyk, Merkel ponawia ofertę dla Polski, ,Rzeczpospolita” z dnia 15 stycznia 2007 r.

${ }^{63}$ Polska/Fotyga: Gazociag Pólnocny zachwiał naszymi stosunkami z Niemcami, „PAP” z dnia 25 stycznia 2007 r.

64 Zob. B. Koszel, Polska i Niemcy..., op. cit., s. 194. Zob. również: Putin gibt sich verlässlich, „Frankfurter Rundschau” z dnia 21 stycznia 2007 r.; Russland Merkel-Rollen am Schwarzen Meer, „Süddeutsche Zeitung” z dnia 21 stycznia 2007 r.; Gipfel: Putin verspricht Energiesicherheit, „Die Zeit” z dnia 21 stycznia 2007 r.; Trefen in Sotschi: Merkel verlangt von Putin ,, bessere Kommunikation”, „Frankfurter Allgemeine Zeitung” z dnia 21 stycznia 2007 r.; A. Pisalnik, P. Jendroszczyk, Merkel i Putin zblizaja Rosję do UE, „Rzeczpospolita” z dnia 22 stycznia 2007 r.; T. Bielecki, Putin i Merkel w Soczi o wspótpracy i dostawach energii, „Gazeta Wyborcza” z dnia 22 stycznia 2007 r.

65 J. Malczyk, Putin $i$ Merkel rozmawiali o bezpieczeństwie energetycznym $i$ wspótpracy Rosja-UE, „PAP” z dnia 21 stycznia 2007 r. Zob. również: R. Schweppe, Pilnie potrzebujemy europejskiej polityki energetycznej, „Rzeczpospolita” z dnia 31 stycznia 2007 r. 
Na początku lutego do Brukseli przyjechali z kampanią promocyjną szefowie spółki Nord Stream AG, budującej Gazociąg Północny na dnie Morza Bałtyckiego ${ }^{66}$. Jak oświadczył Gerhard Schröder „budowa rosyjsko-niemieckiego gazociągu po dnie Bałtyku nie zostanie opóźniona z powodu zastrzeżeń natury ekologicznej i politycznej. [...] Planujemy ukończyć rurociag $\mathrm{w}$ zaplanowanym terminie i nie sądzimy, by było to niemożliwe" ${ }^{, 67}$. Doradca spółki przekonywał, że projekt nie jest tylko niemiecko-rosyjski i że „ma zasadnicze znaczenie z punktu widzenia bezpieczeństwa dostaw gazu nie tylko dla Niemiec, ale również dla Europy". Były kanclerz Niemiec podkreślał, że Gazociąg Północny nie zastąpi innych połączeń ${ }^{68}$. Schröder przypomniał również, że Polska może stać się współpartnerem całego przedsięwzięcia. Oświadczył, że rozumie obawy Polski i traktuje je bardzo poważnie ${ }^{69}$.

W połowie marca kanclerz Angela Merkel udała się z wizytą do Warszawy. Przed podróżą w Niemczech pojawiły się sygnały wskazujące na to, że władze niemieckie przywiązują do niej duże znaczenie, bardzo licząc nie tylko na ogólne ocieplenie stosunków polsko-niemieckich, ale także na porozumienie z Polską w sprawach europejskich ${ }^{70}$. Strona polska była mniej życzliwa. W przeddzień wizyty gazeta „Die Berliner Zeitung” zamieściła wywiad z Mariuszem Muszyńskim, w którym polityk negatywnie określił politykę Niemiec jako „narodową, w swej istocie egoistyczną i przez to niezbyt przyjaźnie nastawioną do Polski”. Według przedstawiciela polskiego MSZ ds. współpracy polsko-niemieckiej „Gazociagg Północny nie tylko poważnie narusza polskie interesy, lecz potencjalnie zagraża również suwerenności państwa polskiego. Ten przykład pokazuje bardzo dobrze, że w stosunkach polsko-niemieckich wciąż istnieje asymetria, że nasi niemieccy partnerzy mają trudności ze zrozumieniem naszych argumentów"71. Podczas wizyty polski prezydent unikał

66 Zob. KE poparta Gazociag Pótnocny, „Gazeta.pl” z dnia 9 lutego 2007 r.

67 Schroeder: Obiekcje polityczne i ekologiczne nie udaremnia gazociagu, „PAP” $\mathrm{z}$ dnia 7 lutego $2007 \mathrm{r}$.

68 Zob. A. Słojewska, Gerhard Schröder lobbuje w Brukseli, „Rzeczpospolita” z dnia 8 lutego 2007 r.

69 Schroeder: Obiekcje polityczne i ekologiczne nie udaremniq gazociagu, „PAP” z dnia 7 lutego 2007 r.

${ }^{70}$ Zob. J. Lepiarz, Niemcy/Merkel chce utorować drogę do porozumienia z Polska w sprawach UE, „PAP” z dnia 14 marca 2007 r.

${ }^{71}$ „Berliner Zeitung”: przedstawiciel polskiego MSZ zarzuca Niemcom egoizm, „PAP” z dnia 15 marca 2007 r. 
drażliwych tematów, a niemiecka kanclerz pokazywała, że rozumie Polskę i że jest jej przyjacielem, apelując jednocześnie, by w sprawach dotyczących bezpieczeństwa nie dopuścić do podziału Europy ${ }^{72}$. Szefowa niemieckiego rządu skomentowała wizytę słowami ,przeprowadziliśmy bardzo dobre rozmowy”, prezydent wtórował dodając, iż „rozmowa była krótka, ale naprawdę treściwa” oraz „myślę, że atmosfera się poprawiła" ${ }^{, 73}$.

Po szczycie Unii Europejskiej z Rosją, który odbył się 18 maja 2007 roku w Samarze, w Republice Federalnej widać było stopniową zmianę nastrojów. Kanclerz A. Merkel z coraz większym sceptycyzmem zaczęła odnosić się do kontynuacji rosyjsko-niemieckiego strategicznego partnerstwa $^{74}$. Po Deklaracji Berlińskiej z okazji 50-lecia Traktatów Rzymskich kanclerz próbowała skonsolidować kraje członkowskie UE, zwłaszcza w kwestii bezpieczeństwa energetycznego i globalnych wyzwań stojących przed Unią ${ }^{75}$.

17 czerwca odbyły się ostatnie przed brukselskim szczytem krótkie konsultacje z władzami polskimi. Kanclerz A. Merkel spotykając się z prezydentem J. Kaczyńskim nie wyraziła chęci zrezygnowania czy zmieniania pakietu reform instytucjonalnych. Uwzględniła jednakże życzenie Polski dodając debatę o polityce energetycznej ${ }^{76}$. Według polskiej minister spraw zagranicznych Anny Fotygi nietraktowanie Polski jako równego partnera było powodem sporów Warszawy z Berlinem, Brukselą

72 Ibidem.

73 W. Lorenz, Lepszy klimat po wizycie Merkel, „Rzeczpospolita” z dnia 19 marca 2007 r. Zob. również: J. Lepiarz, Niemcy/Merkel chce utorować drogę do porozumienia z Polska w sprawach UE, „PAP” z dnia 14 marca 2007 r.

74 Zob. Merkel kritisiert Festsetzung von Oppositionellen, „Die Welt” z dnia 18 maja 2007 r.

75 Zob. B. Koszel, Polska i Niemcy..., op. cit., s. 196-197.

76 Zob. Vor dem EU-Gipfel in Brüssel: Merkel fordert Kompromissbereitschaft, „Frankfurter Allgemeine Zeitung” z dnia 18 czerwca 2007 r. Zob. również: G. Büchner, D. Fras, F. Herold, S. Korte, Merkel legt Vorschläge für EU-Gipfel vor. Kanzlerin spart Streit über Stimmengewichtung aus/Polens Präsident Kaczynski offen für Ausgleich, „Berliner Zeitung” z dnia 15 czerwca 2007 r.; G. Büchner, EU-Vertrag entzweit Deutschland und Polen. Merkel empfängt Staatspräsident Kaczynski in Meseberg, „Berliner Zeitung” z dnia 16 czerwca 2007 r.; EU-Verfassung keinen Schritt vorwärts, „Frankfurter Rundschau” z 18 czerwca 2007 r.; Merkel fordert Kaczynski zum Einlenken auf, „Die Welt” z dnia 18 czerwca 2007 r.; B. Koszel, Polska i Niemcy..., op. cit., s. 67 i 195. 
i Moskwą. W udzielonym w sierpniu amerykańskiemu dziennikowi „International Herald Tribune" wywiadzie szefowa MSZ zaznaczyła, że budowany wspólnie przez Rosję i Niemcy Gazociąg Północny podważa bezpieczeństwo Polski, „podważa europejską solidarność i poddaje w wątpliwość naszą zdolność do dysponowania równym głosem”. Mimo że UE usiłowała opracować wspólną strategię energetyczną wobec wykorzystywania przez Rosję swoich zasobów w charakterze broni politycznej, Fotyga wyraziła swe rozczarowanie powolnym postępem ${ }^{77}$.

Pod koniec sierpnia parlamentarzyści z państw bałtyckich wezwali swoje rządy oraz Unię Europejską, w deklaracji przyjętej na zakończenie 16. Konferencji Parlamentarnej Państw Morza Bałtyckiego w Berlinie, do „gruntownego” zbadania, czy niemiecko-rosyjski projekt Gazociagu Północnego nie stanowi zagrożenia dla środowiska naturalnego oraz czy uwzględnia bezpieczeństwo energetyczne całego regionu nadbałtyckiego. Przedstawiciele polskiego rządu i parlamentu potwierdzili w czasie obrad sprzeciw Polski wobec realizacji kontrowersyjnego gazociagu. Poseł niemieckiej SPD - Franz Thönnes - zaznaczył, że problemów Bałtyku nie można rozwiązywać bez udziału Rosji. Jak mówił polityk ,fakt, że rosyjscy deputowani uczestniczyli w obradach, jest dowodem, że porozumienie jest możliwe"

Dzień po niemiecko-rosyjskich konsultacjach rządowych, na konferencji prasowej Angela Merkel oświadczyła, że budowa Gazociagu Północnego będzie postępować i że oba rządy udzielą pomocy, jeżeli pojawią się przeszkody, ale „na razie nie ma takiej potrzeby”. Szefowa rządu podkreśliła, że „to projekt politycznie pożądany” i po stronie niemieckiej ,jest wola, by dokończyć gazociąg i go wykorzystywać" "79. Parę dni później pojawiła się informacja, że Gazprom chciałby dla siebie i swoich partnerów monopolu na transport przez Niemcy surowca z Nord Stream. Władze w Berlinie nie zgodziły się na to i oświadczyły, że nie udzielą ze-

77 Zob. Francja/Minister Fotyga dla ,IHT, , : Polska nie jest traktowana jak równy partner, „PAP” z dnia 16 sierpnia 2007 r.

78 J. Lepiarz, Parlamentarzyści wzywaja do zbadania skutków budowy Gazociagu Pólnocnego dla Bałtyku, „PAP” z dnia 28 sierpnia 2007 r. Zob. również: Z. Lentowicz, MSZ: Gazociag pótnocny narusza solidarność UE, „Rzeczpospolita” z dnia 28 sierpnia $2007 \mathrm{r}$.

79 B. T. Wieliński, Putin i Merkel chwalq Gazociag Pólnocny, „Gazeta Wyborcza” z dnia 13 października 2007 r. Zob. również: Merkel: Gazociag Pótnocny projektem „politycznie pożadanym”, „Gazeta.pl” z dnia 15 października 2007 r. 
zwolenia na budowę OPAL i NEL ${ }^{80}$, dopóki Gazprom i jego partnerzy nie pozwolą konkurencji na wykorzystanie tych rur $^{81}$.

21 października odbyły się wybory parlamentarne w Polsce. Kandydat na premiera Donald Tusk oświadczył, że liczy na korektę projektu budowy niemiecko-rosyjskiego Gazociagu Północnego. Na spotkaniu z dziennikarzami zagranicznymi w Sejmie lider PO powiedział, że ma nadzieję „że w najbliższym czasie gospodarze tego projektu nieprzymuszeni przez nikogo będą skłonni do bardzo głębokiej jego korekty”. Jego zdaniem „wątpliwości, sceptycyzm, przestrogi strony polskiej w tej kwestii miały naprawdę głębokie uzasadnienie”. Tusk stwierdził, że „to była zła decyzja, a dzisiaj skutek złych decyzji poprzedniego kanclerza staje się poważ-

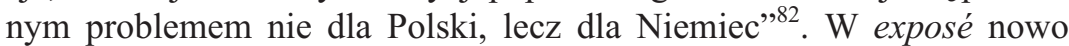
wybrany premier deklarował, że chce rozwijać strategiczne stosunki z Niemcami, nie unikając spraw trudnych. O relacjach polsko-niemieckich mówił, że wymagają „,szczególnej pieczołowitości, braku kompleksów, jasnego, twardego, kiedy trzeba, przyjaznego stawiania wzajemnych problemów i oczekiwań” ${ }^{\prime 3}$. Kanclerz Angela Merkel wyraziła chęć rozmowy z premierem na temat Gazociagu Północnego, ale również m.in. polityki UE wobec Rosji i współpracy Polski i Niemiec ${ }^{84}$.

6 grudnia minister spraw zagranicznych RP Radosław Sikorski złożył roboczą wizytę w Berlinie, gdzie spotkał się z szefem niemieckiego MSZ Frankiem-Walterem Steinmeierem. Podczas spotkania w odniesieniu do kwestii budowy Gazociagu Północnego, Sikorski poinformował, że stanowisko Polski pozostaje niezmienne, choć możliwe jest przeprowadzenie

${ }^{80}$ Po dostarczeniu do terminalu Greifswald na niemieckim wybrzeżu, rosyjski gaz ma być transportowany przez Niemcy dwiema rurami. Pierwszą o nazwie OPAL ma wzdłuż polskiej granicy aż do Czech płynąć $36 \mathrm{mld} \mathrm{m}^{3}$ surowca, począwszy od $2010 \mathrm{r}$. Biegnie ona wzdłuż polskiej granicy do granicy z Czechami i znajdującego się tam połączenia z systemem czeskich rur. W ten sposób gaz, który przez Bałtyk ominie Europę Środkową, będzie można dostarczać także do Czech i na Słowację. Dwa lata później drugą, mniejszą rurą o nazwie NEL ma płynąć w kierunku Holandii i Wlk. Brytanii do $20 \mathrm{mld}^{3}$ gazu. Rury te zbudują firmy E.ON i Wingas.

81 Zob. A. Kublik, Gazprom: Niemcy blokują Gazociag Pótnocny, „Gazeta Wyborcza" z dnia 24 października 2007 r.

82 A. Łakoma, Tusk sugeruje korektę gazociagu pótnocnego, „Rzeczpospolita” z dnia 7 listopada 2007 r. Zob. również: P. Jendroszczyk, Berlin ma nadzieje na przełom w stosunkach z Warszawa, ,Rzeczpospolita” z dnia 29 października 2007 r.

${ }^{83}$ Polska/Premier Tusk złoży wizytę w Berlinie, ,PAP” z dnia 10 grudnia $2007 \mathrm{r}$.

84 Zob. P. Jendroszczyk, Niemcy czekaja na Donalda Tuska, „Rzeczpospolita” $\mathrm{z}$ dnia 28 listopada $2007 \mathrm{r}$. 
konsultacji ze stroną niemiecką na szczeblach eksperckich, w deklarowanym przez nowo wybrany rząd duchu dialogu, tak, aby lepiej poznać racje drugiej strony ${ }^{85}$. Po spotkaniu Steinmeier oświadczył: „cieszę się, że minister Sikorski wyjaśnił w Berlinie dziennikarzom, że nie miał zamiaru porównywać gazociągu do paktu [Ribbentrop-Mołotow - przyp. A. B.], tylko chciał zwrócić uwagę na to, że porozumienia rosyjsko-niemieckie nie powinny być zawierane ponad polskimi głowami. Zaproponowałem mu rozmowy na temat wszystkich polskich obaw. Gazociag nie jest wymierzony przeciwko komukolwiek. Jest i pozostanie europejskim projektem infrastrukturalnym". Minister podkreślał, że jest on budowany przez prywatne przedsiębiorstwa - niemieckie, rosyjskie i holenderskie i dodał, że „bardzo chętnie włączymy do projektu także Polskę”. Zaproponował również, by ministrowie gospodarki usiedli i przedyskutowali to, co Niemcy zaproponowały w zeszłym roku Polsce. Jak podkreślił ,rozumiemy polskie obawy o bezpieczeństwo energetyczne". Dodał także, że „podczas budowy gazociąu muszą być przestrzegane wszystkie europejskie standardy, przepisy i procedury, ze szczególnym uwzględnieniem ekologii. Wszelkie wątpliwości trzeba wyjaśnić” oraz, że „prowadzona zgodnie z przepisami inwestycja nie może być bezpodstawnie blokowana" ${ }^{\prime 86}$.

Przed wizytą premier zapowiadał, że będzie próbował przekonać Berlin i Moskwę do zmiany zdania w sprawie Gazociągu Północnego, do „przemyślenia tej koncepcji”, bo jest przekonany, że można znaleźć rozwiązanie tańsze i bezpieczniejsze z punktu widzenia zarówno Wspólnoty, jak i Rosji. Tusk nie uważał, by „ta instalacja - bardzo kosztowna, powiedziałbym nienaturalna - zwiększała bezpieczeństwo energetyczne Wspólnoty Europejskiej i Polski”, ${ }^{\prime 7}$. Pierwsza wizyta premiera Tuska u kanclerz Merkel określana była jako „czysto kurtuazyjna”, gdyż Niemcy w kwestii Gazociągu Północnego nie miały Polsce nic nowego do zaoferowania ${ }^{88}$.

85 Zob. Komunikat MSZ dot. spotkania Ministra SZ Radosława Sikorskiego z Ministrem SZ RFN Frankiem-Walterem Steinmeierem - Berlin, 6 grudnia 2007 r., http://www.msz.gov.pl/Komunikat,MSZ,dot.,spotkania,Ministra,SZ,Radoslawa,Sikorskiego,z,Ministrem,SZ,RFN,Frankiem-Walterem,Steinmeierem,-,Berlin,,6, grudnia,2007,r.,12562.html, 15.10.2008. Zob. również: P. Jendrosz- czyk, A. Słojewska, Niemcy: bez nowych propozycji dla Polski, ,Rzeczpospolita” z dnia 7 grudnia 2007 r.

${ }_{86}$ B. T. Wieliński, Polsko-niemieckie lody przetamane, „Gazeta Wyborcza” z dnia 10 grudnia $2007 \mathrm{r}$.

${ }_{87}$ Polska/Premier Tusk złoży wizytę w Berlinie, ,PAP” z dnia 10 grudnia $2007 \mathrm{r}$.

${ }^{88}$ Zob. W Berlinie bez tabu, ,PAP” z dnia 12 grudnia $2007 \mathrm{r}$. 
Polska natomiast wciąż nie chciała włączyć się w to przedsięwzięcie. $\mathrm{Na}$ wspólnej konferencji prasowej Donald Tusk i Angela Merkel przyznali, że są tematy, w których nie osiagnęli pełnego porozumienia. Oboje podkreślili, że będą do tych rozmów wracać. Zmieniła się za to atmosfera. W berlińskim urzędzie kanclerskim z ust polskiego premiera i niemieckiej kanclerz padały słowa „przyjaźń” i ,zaufanie”. Tusk dodał nawet, że życzyłby sobie, by stosunki polsko-niemieckie były tak przyjacielskie jak te, które łączą go z Merkel ${ }^{89}$. Premier nie tracił jednak nadziei na zmianę niemieckiego stanowiska. Jak oświadczył: „chcemy przekonać Niemców, że gazociag przechodzący przez Polskę jest bardziej racjonalny ekonomicznie" ${ }^{\prime 90}$. O projekcie Nord Stream oraz o gazociagu alternatywnym (Amber) ze stroną niemiecką rozmawiał również towarzyszący premierowi Tuskowi wicepremier i minister gospodarki Waldemar Pawlak ${ }^{91}$.

W styczniu 2008 roku podczas przesłuchania w Komisji Petycji wiceminister środowiska i główny konserwator przyrody Maciej Trzeciak zaapelował, by KE zablokowała budowę Gazociagu Północnego. Polski rząd wskazywał m.in. na zagrożenie dla polskich obszarów Natura 2000, jak Zatoka Pomorska i Ławica Słupska, choć nie leżały one bezpośrednio na planowanej trasie gazociagu ${ }^{92}$. Nie zważając na protesty, pod koniec miesiąca kierownictwo niemieckiego koncernu E.ON zaapelowało do Komisji Europejskiej o zwiększenie poparcia dla projektu budowy Gazociągu Północnego. Podczas konferencji energetycznej w Berlinie członek zarządu spółki E.ON Burckhard Bergmann nazwał gazociąg projektem europejskim, a nie tylko niemiecko-rosyjskim. Biznesmen zapewnił, że inwestycja zostanie zrealizowana $\mathrm{z}$ zachowaniem najwyższych standardów ekologicznych ${ }^{93}$. Nie było to do końca prawdą. Pod koniec lutego

89 Zob. Tusk po spotkaniu z kanclerz Merkel: Nie będzie tematów tabu, „Gazeta.pl" z dnia 11 grudnia 2007 r.

90 Zob. W Berlinie bez tabu, op. cit. Zob. również: „Dziennik”/Merkel: $3 x$ NIE, „PAP” z dnia 12 grudnia 2007 r.

91 Zob. P. Jendroszczyk, Na polskiego premiera nie czeka $w$ Berlinie żadna niespodzianka, „Rzeczpospolita” z dnia 11 grudnia 2007 r. Zob. również: Pawlak chce rozmawiać z Niemcami i Rosja o gazociagu, „PAP” z dnia 03 grudnia 2007 r.; Pawlak: Gazociag Amber może być projektem UE, „PAP” z dnia 14 grudnia 2007 r.

92 Libicki: W lipcu decyzja PE w sprawie raportu o Nord Stream, „PAP” z dnia 9 kwietnia 2008 r.

93 Zob. Niemiecki E.ON apeluje do UE większe poparcie Gazociagu Ptn., „Gazeta.pl" z dnia 23 stycznia 2008 r. Zob. również: H. Janiszewski, Macki Gazpromu oplataja Europę, „Rzeczpospolita” z dnia 1 lutego 2008 r. 
tygodnik „Der Spiegel” poinformował, że kierowane przez Gazprom konsorcjum Nord Stream zastanawiało się nad użyciem trujących płynów - Glutaraldehydu - do czyszczenia rurociągu, a następnie wypompowaniem ponad dwóch miliardów litrów tego płynu do Bałtyku. Niemiecki rząd informację potwierdzi194.

6-7 kwietnia 2008 roku na zaproszenie ministra Radosława Sikorskiego wizytę w Polsce złożył szef niemieckiego MSZ Frank-Walter Steinmeier $\mathrm{z}$ małżonką ${ }^{95}$. Jeszcze przed spotkaniem minister w udzielonym wywiadzie mówił, że w politycznie tak gorąco dyskutowanej kwestii Gazociagu Bałtyckiego widział pole do poszukiwania wspólnych rozwiązań. „Ten projekt - według ministra - jest częścią Sieci Transeuropejskich, gdyż Europa tak czy inaczej potrzebuje dodatkowych mocy przesyłowych. W duchu solidarności europejskiej Niemcy i Polska mogłyby stworzyć na swojej granicy możliwości techniczne gwarantujące w razie zakłóceń w dostawach, by gaz i elektryczność mogły płynąć również z Niemiec do Polski. [...] Nie mam jednak złudzeń. Będziemy potrzebowali wiele sił i cierpliwości, aby pokonać te trudności, które są nieuniknione" ${ }^{\text {"96. }}$.

W czerwcu polityk CDU i koordynator niemieckiego MSZ ds. współpracy z Rosją Andreas Schockenhoff oświadczył, że Gazociąg Północny jest potrzebny UE, i wykluczył rezygnację z jego budowy. Dodał, że ,porównywanie tej inwestycji do paktu Hitler-Stalin jest absolutnie nie do przyjęcia, ale trzeba przyznać, iż w jej wyniku powstały szkody polityczne" ${ }^{97}$. Parę dni później w Berlinie spotkali się prezydent Rosji i kanclerz Niemiec. Po rozmowie Dmitrij Miedwiediew i Angela Merkel złożyli deklarację, że Rosja i Niemcy będą przekonywać europejskich partnerów do konieczności jego budowy. Na konferencji prasowej podkreślili strategiczne znaczenie tej inwestycji. Kanclerz przyznała, że nie udało się jeszcze w tej sprawie przezwyciężyć wszystkich trudności. Polityk zapowiedziała, że obie strony będą dążyły do likwidacji zastrzeżeń krajów, które - jak to określiła - mogą poczuć się wykluczone z pro-

94 Zob., „Der Spiegel”: Gazociag Pólnocny groźny dla Bałtyku, „Gazeta.pl” z dnia 24 lutego 2008 r. Zob. również: Nordstream zbuduje Gazociag Północny bez zatruwania Battyku?, „PAP” z dnia 27 lutego 2008 r.

95 F.-W. Steinmeier, Pamiętajac budować przyszłość, „Fakt” z dnia 15 kwietnia 2008 r.

96 F.-W. Steinmeier, Europejski Dom, ,Dziennik” z dnia 5 kwietnia 2008 r.

97 Polityk CDU: Gazociag Pólnocny przynióst UE polityczne szkody, „PAP” z dnia 3 czerwca 2008 r. 
jektu lub uważać, że skierowany jest przeciwko ich interesom ${ }^{98}$. W tym celu Merkel wybierała się z oficjalną wizytą do Polski. Podczas niej, według Karla-Georga Wellmanna, kanclerz chciała załagodzić sprawę gazociagu ,proponując włączenie Polski, a także krajów bałtyckich do sieci europejskich tras przesyłowych. To pozwoliłoby na zwiększenie ich bezpieczeństwa energetycznego" "99. Nie było to jednakże łatwe zadanie, gdyż na szczycie Rady Państw Morza Bałtyckiego w Rydze polski premier Donald Tusk po raz kolejny oświadczył, że „stanowisko Polski nie uległo zmianie - Warszawa opowiada się za tranzytem rosyjskiego gazu do Europy drogą lądową"100.

Podczas spotkania Tusk nie chciał poruszać drażliwych kwestii, dlatego nie wspomniano o spornym gazociagu ${ }^{101}$. Nie oznaczało to jednak, że dyskusja ucichła. Pod koniec miesiąca PiS zorganizował w Szczecinie konferencję o bezpieczeństwie energetycznym kraju i UE. Prezes PiS Jarosław Kaczyński, wiceprzewodniczący Parlamentu Europejskiego Adam Bielan oraz byli ministrowie środowiska i skarbu w rządzie PiS Jan Szyszko i Wojciech Jasiński ${ }^{102}$ uznali, że aby działania zapewniające bezpieczeństwo energetyczne kraju były możliwe, niezbędna była ,zgodna współpraca" premiera z prezydentem w tym zakresie, powołanie pełnomocnika rządu ds. dywersyfikacji dostaw nośników energii, a także „,konsekwentne blokowanie" Nord Stream ${ }^{103}$. Dwa dni później europoseł Marcin Libicki argumentował na antenie „Sygnałów Dnia” w Programie Pierwszym Polskiego Radia, że - jak wynika z analiz - budowa gazociagu po dnie Morza Bałtyckiego będzie około trzy razy droższa, niż gdyby został on poprowadzony drogą lądową. Ostrzegt, że skutki ewentualnej katastrofy ekologicznej, spowodowanej przez gazociąg, będą odczuwalne przez kilka

98 Zob. Miedwiediew w Niemczech: razem z Merkel przekonamy Europę do rurociagu, „Gazeta.pl” z dnia 5 czerwca 2008 r. Zob. również: Polska/Kanclerz Niemiec Angela Merkel w poniedziałek z wizyta w Gdańsku, „PAP” z dnia 13 czerwca 2008 r.

99 Zob. A. Widzyk, Niemcy/Poset CDU: Niemcy przychylne Wschodniemu Partnerstwu i muzeum II wojny światowej, „PAP” z dnia 13 czerwca 2008 r.

100 Gazociag Pótnocny - państwa nadbattyckie zmienity zdanie?, „Gazeta.pl” z dnia 6 czerwca 2008 r.

101 Zob. A. Widzyk, „FTD”/Niemcy ignoruja zastrzeżenia Polski, „PAP” z dnia 17 czerwca 2008 r.

102 Zob. J. Kaczyński: należy zrobić wszystko, aby zdywersyfikować dostawy gazu, „PAP” z dnia 28 czerwca 2008 r.

103 Zob. PiS: zapewnienie bezpieczeństwa energetycznego kluczowym zadaniem państwa, „PAP” z dnia 28 czerwca 2008 r. 
następnych pokoleń. Zdaniem polityka, sprawa była skomplikowana, przede wszystkim dlatego, że miała charakter polityczny ${ }^{104}$.

W połowie lipca niemiecka agencja dpa napisała, że Aleksander Kwaśniewski jako pierwszy z czołowych polskich polityków opowiedział się za kontrowersyjnym Gazociagiem Północnym. Według agencji, deklaracja ta miała paść podczas wywiadu udzielonego portalowi „Der Westen”. Były prezydent Polski miał w nim powiedzieć, że gazociąg budowany na dnie Bałtyku daje także Polsce szansę na bezpieczne i niezawodne zaopatrzenie w energię ${ }^{105}$. Zdaniem Kwaśniewskiego ważne było, jak napisała dpa, żeby Polskę przyłączyć do Gazociągu Północnego, gdyż mogło to rozwiać istniejące w Polsce obawy przed wstrzymaniem dostaw gazu z Rosji. Kwaśniewski wyraził ubolewanie z powodu braku dialogu z Polską i wymiany informacji oraz braku przejrzystości w początkowej fazie projektu gazociagu. Według byłego prezydenta skutki tego błędu były do dziś odczuwalne w Polsce ${ }^{106}$. Polityk oświadczył w „Rzeczpospolitej”, że jego wypowiedź ,została wyolbrzymiona”. Jak zaznaczył do sprawy gazociagu należy podchodzić pragmatycznie. Według Kwaśniewskiego „,nie ma co zamykać oczu na fakty. Jeżeli nie uda się zablokować gazociagu ze względu na zagrożenie dla środowiska, Polska powinna się włączyć w projekt. Rurociąg może być częścią wspólnej europejskiej polityki energetycznej i w ten sposób możemy na tym projekcie skorzystać"107. Wywiady te rozpętały polityczną awanturę. Wielu polityków z różnych ugrupowań ostro skrytykowało słowa Kwaśniewskiego ${ }^{108}$. Zbigniew Chlebowski z PO zapewnił, że stanowisko rządu w tej sprawie jest

104 Gazociag Pólnocny zagraża środowisku, ,Gazeta.pl” z dnia 30 czerwca 2008 r. Analiza środowiskowa zlecona przez spółkę Nord Stream AG miała zostać przekazana do zatwierdzenia władzom Rosji, Finlandii, Szwecji, Danii i Niemiec jako stronom w rozumieniu. Zgodnie z konwencją z Espoo każda tego typu inwestycja powinna być poprzedzona analizą wpływu na bezpieczeństwo środowiska naturalnego, przy konsultacji wszystkich państw przybrzeżnych. Zob. również: PE o Gazociagu, „Gazeta.pl" z dnia 8 lipca 2008 r.

105 Zob. P. Zychowicz, Kwaśniewski: Nord Stream może być korzystny dla Polski, „Rzeczpospolita” z dnia 17 lipca 2008 r. Zob. również: P. Zychowicz, Kwaśniewski popart gazociag, „Rzeczpospolita” z dnia 17 lipca 2008 r.

106 Zob. Kwaśniewski opowiedziat się za Gazociagiem Pótnocnym, „Gazeta.pl” z dnia 16 lipca 2008 r.

107 „Rzeczpospolita”: Kwaśniewski za pragmatycznym podejściem do Gazociagu Pólnocnego, „PAP” z dnia 17 lipca 2008 r.

108 Zob. K. Manys, Kwaśniewski zbiera cięgi za gazociag, „Rzeczpospolita” z dnia 18 lipca 2008 r. 
jednoznaczne. Jak oświadczył „Polsce potrzebna jest dywersyfikacja dostaw"109.

Do blokowania gazociagu strona polska próbowała wykorzystać również pogorszenie się stosunków niemiecko-rosyjskich po wojnie w Gruzji. We wrześniu Donald Tusk na łamach niemieckiego dziennika „Neue Osnabrücker Zeitung" zażądał, by ponownie przeanalizowano projekt rosyjsko-niemieckiego Gazociagu Północnego. Jak zaznaczył szef polskiego rządu, każdy odpowiedzialny europejski polityk musi się znacznie mocniej niż przed czterema tygodniami zastanowić, czy takie przedsięwzięcia majaj jeszcze w ogóle sens i dodał, że „nie wolno zwiększać zależności od Rosji poprzez projekty tego rodzaju". Stanowisko Tuska zostało natychmiast zakwestionowane przez polityków niemieckich. Jak powiedział tygodnikowi „Welt am Sonntag” szef grupy posłów bawarskiej CSU w Bundestagu Peter Ramsauer „,musimy zmniejszyć zależność od importu, ale to, by po prostu nie budować żadnych nowych rurociagów, jest błędną drogą". Współprzewodniczący opozycyjnych Zielonych Reinhard Bütikofer przyznał, że stawiany przez Tuska postulat jednolitego stanowiska UE wobec Rosji w sferze polityki energetycznej jest słuszny. „Dziwi mnie w każdym razie - powiedział polityk - że teraz polski premier w ogóle kwestionuje ten gazociag. Do tej pory Polska agitowała za tym, by jako «Rurociag Bursztynowy» prowadził on przez państwa nadbałtyckie i jej własne terytorium" ${ }^{110}$. Zasadność budowy Gazociagu Północnego zakwestionował Karl-Theodor zu Guttenberg. Ekspert do spraw międzynarodowych bawarskiej CSU w wywiadzie dla tygodnika „Rheinischer Merkur" przestrzegł przed możliwością wykorzystania inwestycji przez Rosję w celu uzależnienia Zachodu od dostaw energetycznych. Bawarski deputowany już wcześniej sceptycznie wypowiadał się na temat kontrowersyjnej inwestycji ${ }^{11}$.

Parę dni później podczas konferencji prasowej w Gołdapi premier RP powiedział, że „Niemcy zaczynają rozumieć, że samo poczęcie tej idei [Gazociagu Północnego - przyp. A. B.] było w grzechu”. Jego zdaniem

109 Kwaśniewski: Polska powinna podłaczyć się do Gazociagu Pólnocnego, jeżeli..., „Gazeta.pl” z dnia 17 lipca 2008 r. Zob. również: M. Wojciechowski, Chybiona krytyka Kwaśniewskiego, „Gazeta Wyborcza” z dnia 17 lipca 2008 r.

110 Tusk: czy Gazociag Pótnocny ma sens? Niemcy: oczywiście, „PAP” z dnia 6 września 2008 r.

111 Zob. Niemiecki polityk przeciw budowie Gazociagu Pólnocnego, „Gazeta.pl” z dnia 4 września 2008 r. Zob. również: Niemiecki poset: Będziemy zakładnikami Gazociagu Pólnocnego, „PAP” z dnia 3 września 2008 r. 
„Z całą pewnością każde państwo europejskie, które chce być wiarygodne wewnątrz Unii nie może lekceważyć problemu solidarności energetycznej. Niemcy z całą pewnością stoją przed poważnym egzaminem i mam nadzieję, że zdadzą ten egzamin" "12. Oficjalnie, rząd federalny nie widział potrzeby otwierania na nowo debaty na temat Gazociąu Północnego. Jak powiedział zastępca rzecznika rządu w Berlinie Thomas Steg „stanowisko kanclerz Angeli Merkel nie zmieniło się. Gazociąg Północny to projekt gospodarczy"113. Miesiąc później kanclerz Merkel ponownie potwierdziła zaangażowanie Niemiec w Nord Stream słowami: „to ważny dla nas projekt"114.

W listopadzie premier Władimir Putin oświadczył państwom europejskim, że wstrzyma budowę Gazociągu Północnego, jeśli nie będą one zainteresowane odpowiednią ilością surowca ${ }^{115}$. Dodał, że Rosja gotowa jest rozważyć alternatywne drogi eksportu gazu ${ }^{116}$. Komentując tę wypowiedź Tusk odparł, że mając na uwadze światowy kryzys „Polska przewidywała taki przebieg zdarzeń"117. Do słów premiera Putina odniósł się również Jarosław Kaczyński, który powiedział, że Polska powinna namawiać do rezygnacji z budowy Gazociągu Północnego, gdyż ta inwestycja bije w samą istotę Unii Europejskiej - solidarność. Zdaniem szefa PiS „rezygnacja z tej fatalnej inwestycji byłaby wielkim dniem Unii Europejskiej”. W opinii byłego szefa rządu nikt nie może mieć żadnej wątpliwości, że budowa Gazociągu Północnego stwarza ,poważne niebezpieczeństwo dla Polski i innych krajów"118.

Pod koniec roku można było zauważyć, że strona polska zaprzestała ciągłej krytyki budowy Gazociagu Północnego, temat ten nie został nawet

112 Premier: Gazociag Pólnocny narusza zasadę solidarności w UE, „PAP” z dnia 8 września 2008 r.

113 Ibidem.

114 A. Kublik, Niemcy i Rosja wsparty Gazociag Północny, „Gazeta Wyborcza” z dnia 2 października 2008 r. Zob. również: Niemiecki „Financial Times” chwali Tuska, „Gazeta Wyborcza” z dnia 11 października 2008 r.

115 "Zob. Kaczyński: Rezygnacja z Gazociagu Pólnocnego wielkim dniem UE, „PAP” z dnia 13 listopada 2008 r.

116 Zob. Putin grozi Europie wstrzymaniem budowy Gazociagu Pótnocnego, „PAP” $\mathrm{z}$ dnia 12 listopada $2008 \mathrm{r}$.

117 S. Lucyk, Donald Tusk: bliżej porozumienia ws. pakietu energetycznego, „PAP” z dnia 13 listopada 2008 r.

118 Zob. Kaczyński: Rezygnacja z Gazociagu..., op. cit. Zob. również: A. Słojewska, Rura pod Battykiem traci blask, ,Rzeczpospolita” z dnia 14 listopada 2008 r. 
poruszony podczas polsko-niemieckich konsultacji międzyrządowych ${ }^{119}$. Prawdopodobnie na taką postawę wpływ miały pojawiające się - głównie z powodu kryzysu gospodarczego - wątpliwości, czy w ogóle niemiecko-rosyjski gazociag, który jak skomentował R. Sikorski „był obciążeniem dla stosunków polsko-niemieckich" powstanie ${ }^{120}$.

W styczniu 2009 roku konsorcjum oświadczyło, że chce jak najszybciej rozpocząć oficjalne starania o pozwolenia na inwestycję. Dyrektor wykonawczy rosyjsko-niemieckiej spółki Wingas - Rainer Seele - powiedział, że ,problemy z tranzytem przez Ukrainę powinny przekonać ostatnich wątpiących w Szwecji, Polsce i krajach bałtyckich, że bezpośrednie połączenie UE ze źródłami gazu ziemnego na Syberii jest ubezpieczeniem na życie" ${ }^{21}$. Mimo problemów ze zdobyciem kredytów, szef Gazpromu - Aleksiej Miller - zapewniał, że „Gazociag Nord Stream powstanie zgodnie z planem do końca 2011 roku”, dodając, że „to najtańszy korytarz eksportowy gazu"

W czerwcu szef niemieckiego MSZ Frank-Walter Steinmeier komentując obawy Polski, że Gazociąg Północny umożliwi Rosji szantaż gazowy, powiedział, że są one „bezpodstawne”, a pojawiające się wypowiedzi, że jest to rosyjsko-niemieckie przedsięwzięcie określił jako „nieprawdę”. Według ministra „to projekt europejski, który zwiększy bezpieczeństwo energetyczne wszystkich. Zużycie energii będzie rosło i potrzebujemy więcej gazociągów" ${ }^{\prime 23}$. W podobnym tonie wypowiadała się miesiąc później Angela Merkel. Kanclerz potwierdziła po raz kolejny poparcie dla „strategicznego i ważnego" projektu Gazociagu Północnego i zapowiedziała wsparcie w procesie uzyskiwania pozwoleń na inwestycję od państw, przez których strefy gospodarcze prowadzić ma trasa gazociagu $^{124}$.

119 Zob. P. Jendroszczyk, Pół rzqdu Niemiec w Warszawie, „Gazeta Wyborcza” $\mathrm{z}$ dnia 9 grudnia $2008 \mathrm{r}$.

${ }^{120}$ G. Gnauck, ,Für eine neue Ostpolitik”, „Die Welt” z dnia 9 września 2008 r.

121 Zob. „Die Welt”: projekt Nord Stream wkracza w gorqca faze, „PAP” z dnia 23 stycznia 2009 r.

122 Zob. Gazociag Pótnocny budzi irytację nad Battykiem, „Gazeta Wyborcza” z dnia 12 czerwca 2009 r. Zob. również: Czy Rosja buduje argumenty za budowa Gazociagu Pótnocnego, „Rzeczpospolita” z dnia 7 stycznia 2009 r.

${ }_{123}$ B. T. Wieliński, Szefniemieckiego MSZ: Wiemy, jaka odpowiedzialność spoczywa na Niemcach, „Gazeta Wyborcza” z dnia 16 czerwca 2009 r.

${ }_{124}$ Zob. Niemcy i Rosja zachwalaja Nord Stream, „Rzeczpospolita” z dnia 16 lipca $2009 \mathrm{r}$. 
W tym czasie w prasie polskiej z dużym natężeniem zaczęły pojawiać się informacje, że budowa gazociągu może zniweczyć plany importu skroplonego gazu z Kataru, gdyż po jego ułożeniu głębokość toru skurczy się, co uniemożliwi wpływanie gazowców ${ }^{125}$. Konsorcjum poinformowało, że sprawę dostępu do polskich portów - np. na nowych trasach - strona polska ma uzgodnić z rządem Niemiec. W wysłanym 10 września stanowisku Nord Stream, które niemieckie ministerstwo transportu przekazało stronie polskiej, inwestorzy Gazociagu Północnego wskazywali, że takie głębsze tory można znaleźć na terenie niemieckich wód i wymagają one wydłużenia o $10 \mathrm{~km}$ trasy żeglugowej do portów w Świnoujściu i Szczecinie. Ani rząd niemiecki, ani polski nie podjęły jednakże w tym czasie żadnych negocjacji w tej sprawie ${ }^{126}$.

W październiku ruszyła budowa lądowej odnogi Gazociagu Północnego wzdłuż niemieckiej granicy. Kładzenie rury OPAL planowano ukończyć w dwa lata. Dania jako pierwsze państwo nad Bałtykiem zgodziła się, aby konsorcjum Nord Stream ułożyło gazociąg na jej wodach ${ }^{127}$. Następnie zezwolenia wydały Szwecja i Finlandia ${ }^{128}$. Jak skomentował J. Kaczyński decyzja ta była „fatalna dla Polski” i dodał, że teraz jedyną szansą na jego zablokowanie było oprotestowanie go z powodów ekologicznych $^{129}$. Premier Tusk oświadczył, że Polska dostrzega w tym przedsięwzięciu ,zarówno kwestie ekonomiczne, ale także kontekst polityczny"130. Natomiast wicepremier Waldemar Pawlak w Programie Pierwszym Polskiego Radia zwrócił uwagę na to, że prawdopodobnie budowa Gazociagu Północnego po dnie Bałtyku nie pójdzie tak szybko, jak planują inwestorzy. Już podczas prac przygotowawczych pojawiły się bowiem

125 Surowiec miał być przez 20 lat dostarczany do gazoportu, który ma zostać wybudowany w Świnoujściu do 2014 roku. Zob. A. Kublik, Gazociag Pótnocny zatrzyma gaz z Kataru, „Gazeta Wyborcza” z dnia 23 czerwca 2009 r. Zob. również: A. Kublik, Gazociag Pólnocny zablokuje polskie porty, „Gazeta Wyborcza” z dnia 1 października 2009 r.

126 Zob. A. Kublik, Gazociag Pólnocny zatrzyma gaz z Kataru, op. cit.

127 Zob. A. Kublik, Europę podzieli kurtyna gazociagów. A gazoport pod nóż?, „Gazeta Wyborcza” z dnia 21 października 2009 r.

128 Zob. A. Kublik, Szwecja i Finlandia zezwalaja na Gazociag Pótnocny, „Gazeta Wyborcza" z dnia 5 listopada 2009 r.

129 J. Kaczyński: Za naszych czasów była grypa ptasia, teraz jest świńska, „Gazeta.pl" z dnia 6 listopada 2009 r.

130 Zob. Premier: Gazociag Pólnocny musi budzić opór części krajów UE, „PAP” $\mathrm{z}$ dnia 6 listopada $2009 \mathrm{r}$. 
trudności. Zdaniem wicepremiera, w obecnych warunkach ta inwestycja nie jest uzasadniona z punktu widzenia gospodarczego i ma charakter polityczny $^{131}$.

Wciąż aktualna była propozycja kanclerz Angeli Merkel, aby Polska podłączyła się do Gazociągu Północnego poprzez niemiecką sieć gazo-

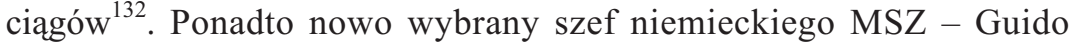
Westerwelle - zapewnił ministra Radosława Sikorskiego, że Niemcy wydadzą zezwolenia z zastrzeżeniem, że gazociąg Nord Stream zostanie ułożony tak, by nie utrudnić dostępu do polskich portów. Choć nie było wiadomo, co konkretnie miało zrobić konsorcjum, rzecznik polskiego ministerstwa - Piotr Paszkowski - skomentował, że rozwiązany został wielki spór, w który Nord Stream mógł uwikłać Warszawę i Berlin. W połowie grudnia niemiecki land Meklemburgia-Pomorze wydał pozwolenie na budowę odcinka Gazociagu Północnego na niemieckich wodach terytorialnych i przybrzeżnych. Według doniesień niemieckiego tygodnika „Focus” Nord Stream wystapił do Niemiec o pomoc publiczną w wysokości 2,8 mld euro w formie kredytów i poręczeń na realizację inwestycji. Spłata miałaby się rozpocząć po zakończeniu budowy pierwszej nitki Gazociagu Północnego i potrwać przez 13 lat ${ }^{133}$. Następnie zgodę na budowę wydał niemiecki Federalny Urząd Żeglugi i Hydrografii oraz Rosja ${ }^{134}$. Budowa gazociagu po dnie Morza Bałtyckiego ma ruszyć w kwietniu 2010 roku, realizacja projektu planowo zostanie zakończona do 2012 roku.

$* * *$

Od momentu podpisania umowy we wrześniu 2005 roku trudności w porozumieniu Polski i Niemiec odnośnie budowy gazociagu Północnego pogłębiało m.in. odmienne stanowisko przedstawicieli obu rządów do

131 Zob. Pawlak: Polska nie musi podtaczać się do planowanego Gazociagu Pólnocnego, „Gazeta.pl” z dnia 12 listopada 2009 r.

132 M. Wojciechowski, Gazociag Pótnocny: Pożyjemy, zobaczymy, „Gazeta Wyborcza" z dnia 8 listopada 2009 r.

133 Zob. Niemcy. W poniedziałek pozwolenie na Gazociag Północny, „PAP” z dnia 18 grudnia 2009 r.

134 Zob. A. Kublik, Gazociag Pólnocny tuż, tuż. Niemcy daja zgode,, „Gazeta Wyborcza" z dnia 22 grudnia 2009 r. Zob. również: Gazociag Pótnocny dostat drugie, ostatnie zezwolenie w Niemczech, „Gazeta Wyborcza” z dnia 28 grudnia 2009 r.; P. Jendroszczyk, Urząd żeglugi zgadza się na gazociag, „Rzeczpospolita” z dnia 28 grudnia 2009 r. 
tej inwestycji, jak również do współpracy z Rosją. Obrońcą budowy gazociągu i wielkim propagatorem przyjaźni niemiecko-rosyjskiej był kanclerz Gerhard Schröder, który zresztą po skończonej kadencji objął stanowisko przewodniczącego rady nadzorczej konsorcjum Nord Stream, jak i, choć w mniejszym stopniu, jego następczyni - Angela Merkel, która przyjaźń w stosunkach z Rosją zamieniła na strategiczne partnerstwo. Konsekwentnie przeciwko gazociągowi opowiadali się prezydent Lech Kaczyński oraz kolejni premierzy Kazimierz Marcinkiewicz, Jarosław Kaczyński oraz Donald Tusk. Strona polska przeciwna była również zacieśnianiu więzi Niemiec i Unii Europejskiej z Rosją w celu zapewnienia bezpieczeństwa energetycznego.

Wizyty oraz zapewnienia niemieckie, których w latach 2005-2009 było całkiem sporo, miały na celu uspokoić Warszawę, jednakże nie oznaczały zmian przyjętego kursu. RFN proponowała włączenie się strony polskiej w tą inwestycję, budowę odnogi gazociagu prowadzącą do Polski i modyfikacje niemieckich przepompowni na gazociagu jamalskim, które pozwoliłyby na tłoczenie gazu z Niemiec, gdyby Rosjanie wstrzymali dostawy. Mimo prób rządu federalnego przekonywania do poparcia projektu strona polska konsekwentnie odmawiała udziału w nim, oficjalnie nie wyraziła również poparcia dla budowy odnogi gazociagu do Polski. Uporczywa postawa Polski nie wpłynęła na zmianę stanowiska Niemiec w tej kwestii, natomiast całkowicie odmienne podejście obu rządów wywarło wpływ na stosunki polsko-niemieckie. Mimo wielokrotnych prób przełamania impasu i słów o polepszeniu oraz dobrych stosunkach były one dość napięte. Dopiero po rezygnacji strony polskiej z ciągłej krytyki projektu gazociagu pod koniec 2008 roku nastąpiło widoczne ich odprężenie.

W styczniu 2010 roku szef dyplomacji Radosław Sikorski ocenił, że stosunki polsko-niemieckie są dobre i stają się coraz lepsze. Na posiedzeniu sejmowej Komisji Spraw Zagranicznych Sikorski oświadczył jednak, że nie zmienił zdania na temat projektu Gazociągu Północnego i nadal uważa, iż jest to porozumienie ,zawarte ponad naszymi głowami” i ekonomicznie nieracjonalne. Jak powiedział minister „to jest marnowanie pieniędzy europejskich konsumentów. Jest alternatywna, nadal do wzięcia droga lądowa, czyli dokończenie inwestycji jamajskiej" ${ }^{135}$. Słowa te sugerują, że jeszcze przez długi czas gazociąg będzie powodem sporów oraz będzie wpływał na bilateralne stosunki polsko-niemieckie.

135 Sikorski o przyjaźni polsko-niemieckiej, „PAP” z dnia 6 stycznia 2010 r. 


\section{Bibliografia}

Adamski Ł., Niemieckie przewodnictwo w UE - zarys wstepnych koncepcji dotyczacych Europy Wschodniej i Rosji, „Biuletyn PISM” 2006, nr 55.

Buras P., Między europeizacja a Gazpromem. Niemcy, Rosja i bezpieczeństwo energetyczne, „Centrum Stosunków Międzynarodowych. Raporty i Analizy”, nr 7.

Exposé premiera Jarosława Kaczyńskiego, Kancelaria Prezesa rady Ministrów, http://www.kprm.gov.pl/archiwum/1433_18017.htm, 15.07.2008.

Exposé premiera Kazimierza Marcinkiewicza, Warszawa, 10 listopada 2005, http://www.kprm.gov.pl/archiwum/4751_14848.htm, 15.01.2006.

Franke J., Die Russlandpolitik der Großen Koalition. Eine (Zwischen-) Bilans nach einem Jahr, w: Polacy i Niemcy w XX wieku. Nowe oblicza partnerstwa, red. B. Koszel, Poznań 2007.

Götz R., Deutsch-russische Energiebeziehungen - auf einem Sonderweg oder auf europäischer Spur? Diskussionspapier. Forschungsgruppe Rusland/GUS, „SWP” 2006, nr 5.

Guział A., Miejsce Rosji w polityce zagranicznej RFN a szansa na wspólnq politykę wschodniq UE, „Przegląd Zachodni” 2006, nr 2.

Jacobson H.-D., Machowski H., Dimensionen einer neuen Ostpolitik der EU, „Aus Politik und Zeitgeschichte" 2007, t. 10.

Komunikat MSZ dot. spotkania Ministra SZ Radosława Sikorskiego z Ministrem SZ RFN Frankiem-Walterem Steinmeierem - Berlin, 6 grudnia 2007 r., 7.12.2007, http://www.msz.gov.pl/Komunikat,MSZ, dot.,spotkania,Ministra,SZ,Radoslawa,Sikorskiego,z,Ministrem,SZ,RFN,Frankiem-Walterem,Steinmeierem,-,Berlin,,6,grudnia,2007,r.,12562.html, 15.10.2008.

Koszel B., Polska i Niemcy w Unii Europejskiej. Pola konfliktów i płaszczyzny wspótpracy, Poznań 2008.

Gemeinsam für Deutschland - mit Mut und Menschlichkeit. Koalitionsvertrag zwischen CDU, CSU und SPD, Berlin 11.11.2005, http://www.cdu.de/doc/pdf/ 05_11_11_Koalitionsvertrag_Navigierbar.pdf, 15.11.2006.

Marhold H., Deutsche Europapolitik nach dem Regierungswechsel 2005, „Integration" 2006, nr 1.

Meier Ch., Die , grosse Koalition” "und die deutsch-russische Partnerschaft: Kontinuität und neue Akzente, „Przegląd Stosunków Międzynarodowych” 2006, nr 2.

Minister Gospodarki, Polityka dla przemystu gazu ziemnego, Warszawa, 20 marca 2007 r., http://www.mg.gov.p1/NR/rdonlyres/F705CB79-27FB-43B0-86AC-388B0BFF4F5B/30401/politykagazowa.pdf, 15.12.2008.

Podolski A., Gaz narodowy czy europejski. Polityczne i historyczne uwarunkowania percepcji wybranych wyzwań dla bezpieczeństwa energetycznego $R P$, „Centrum Stosunków Międzynarodowych. Raporty i Analizy” 2007, nr 2. 
Premier Jarosław Kaczyński złożyt 30.10.06 jednodniowa wizyte roboczq w RFN, http://www.pol-niem.pl/index.php?page=1010600000, 3.11.2006.

Regierungserklärung von Bundeskanzlerin Dr. Angela Merkel vor dem Deutschen Bundestag am 30. November 2005 in Berlin, „Bulletin der Bundesregierung” nr 93-1 z 30.11.2005, http://www.bundesregierung.de/nn_1514/Content/DE/Bulletin/2001_2005/2005/11/2005-11-30-regierungserklaerung-von-bundeskanzlerin-dr-angela-merkel-vor-dem-deutschen-bundestag-.html, 1.03.2006.

Spotkanie Ministra Spraw Zagranicznych RP Pana Stefana Mellera z Ministrem Spraw Zagranicznych RFN Panem Frankiem-Walterem Steinmeierem, http://www.pol-niem.pl/index.php?page=1010600000, 15.12.2005.

\section{Publicystyka:}

„Der Tagesspiegel” 2006; „Der Spiegel” 2006; „Die Berliner Zeitung” 2007; „Die Tageszeitung” 2006; „Die Welt” 2006, 2008; „Die Zeit” 2006-2007; ,Dziennik” 2008; ,Fakt” 2008; „Frankfurter Allgemeine Zeitung” 2006-2007; „Frankfurter Rundschau” 2007; „Gazeta.pl” 2006; „Gazeta Wyborcza” 2005-2009; „Nowy Dzień” 2005; „PAP” 2005-2009; „Polityka” 2006; „Puls Biznesu” 2006; „Rzeczpospolita” 2005-2009; „Süddeutsche Zeitung” 2007.

\section{Summary}

The paper analyzes the impact of the Nord Stream pipeline construction on Polish-German relations from 2005 to 2009 . The author notes that the difficulties in reaching a consensus were further increased by the different attitudes of both governments to this investment as well as to the cooperation with Russia. From the beginning, Chancellor Gerhard Schröder was an advocate of the pipeline construction and a great promoter of German-Russian friendship, an attitude to a somewhat lesser degree also continued by his successor - Angela Merkel. Polish President Lech Kaczyński was consistently against the pipeline, supported by subsequent Prime Ministers of Poland. The Polish side was also against the tightened relations between Germany and the European Union and Russia that were supposed to ensure energy security.

German visits and words of assurance, that were so numerous in the period 2004-2009, were intended to appease Warsaw but they did not mark a change of policy. Although the German government was trying to persuade Poland to support the project, Poland was consistent in its refusal to take part in it. Poland's persistent standpoint has not changed the German attitude in this matter, while the extremely different approaches of both governments have adversely affected Polish-German relations. It was only after the Polish side ceased its continuous criticism of the pipeline project in late 2008 that a clear détente was apparent. 
